\title{
Mentes sacrílegas, palabras impías. Ateísmo y blasfemia en Cataluña, siglos XVI-XVIII
}

\author{
Martí GELABERTÓ VilagRAN \\ Université de Franche-Comté (Francia) \\ gelabertomarti@hotmail.com
}

\section{RESUMEN}

El artículo analiza las interacciones entre el lenguaje blasfematorio y las expresiones de contenido ateísta manifestadas en el vocabulario corriente de las clases populares en el marco de la Cataluña de los siglos XVI-XVIII. A través del estudio de la documentación judicial elaborada por la Inquisición de Barcelona y de la literatura de reforma moral católica postridentina se ponen al descubierto las diversas interpretaciones que suscitaba el tema entre juristas y teólogos, desvelándose las distintas sensibilidades de los grupos sociales y de ciertas profesiones frente a la blasfemia y la desafección religiosa. Un comportamiento irreligioso potencialmente atribuible a la lógica del razonamiento popular o a la herencia de las tradiciones religiosas católica, judía y musulmana en la construcción de la fraseología blasfema cristiana.

Palabras clave: Ateísmo, blasfemia, injuria, religiosidad, Cataluña, Edad Moderna.

Sacrilegious minds, impious words. Atheism and blasphemy in Catalonia, XVI-XVIII centuries

\begin{abstract}
The article analyses the interaction between blasphemous language and atheist content expressions expressed in the current vocabulary of the popular classes in the framework of Catalonia in the XVIXVIII centuries. Through the study of judicial documents draw up by the Inquisition in Barcelona and the literature of post-tridentine catholic moral reform will expose the various interpretations that raised the issue among jurist and theologians, while losing the different sensitivities of social groups and certain professions againts blasphemy and religious disaffection. An irreligious behaviour potentially attributable to the popular reasoning logics or catholic, jewish and muslin religious traditions inheritance in the construction of popular christian blasphemous phraseology.
\end{abstract}

Keywords: Atheism, blasphemy, insult, religion, Catalonia, Modern Age.

SUMARIO: 1. Introducción. 2. Blasfemias versus ateísmo: el debate historiográfico. 3. Teología moral y ateísmo. 4. Las fuentes de la incredulidad religiosa. 4.1. El enemigo interior: el diablo. 4.2. Las aportaciones culturales exteriores: Judaísmo e Islam. 5. Juramentos blasfemos contra Dios y la Virgen. 6. Juramentos blasfemos contra los sacramentos y la espiritualidad cristiana. 7. Conclusiones. 8. Fuentes documentales. 9. Bibliografía. 


\section{INTRODUCCIÓN ${ }^{1}$}

El lenguaje blasfemo es una realidad cotidiana entre la inmensa mayoría de europeos de finales de la Edad Media y el Renacimiento. Teólogos y moralistas condenaban sin miramientos la extendida costumbre de muchos cristianos de blasfemar ante el menor traspié o contrariedad que se les presentaba en el quehacer de la vida diaria y en ciertas situaciones donde los estados de ánimo estaban alterados por el jolgorio festivo del juego o la ingestión desmesurada de alcohol. Las blasfemias -expresiones verbales de carácter sacrílego entendidas en su sentido más amplio de insultos, injurias y juramentos dirigidos a Dios, la Virgen María y los santos- constituyen el principal vector de preocupación del clero reformista en su combate sin cuartel contra los pecados de la lengua. La Iglesia libra una tenaz y larga batalla dirigida a extirpar de las conciencias de los católicos toda exclamación y frase malediciente atentatoria contra la autoridad divina, en un período histórico donde la violencia ordinaria del lenguaje cotidiano estaba muy arraigada en amplios sectores sociales de la península. Casuistas y jurisconsultos elaboran la epistemología y las leyes con las que afrontar los diversos problemas suscitados en los ámbitos moral y legal. Asunto de profundo calado cultural, distintas polémicas doctrinales acompañaran los debates eruditos emprendidos entre eclesiásticos y juristas. La controversia teológica y legislativa de antaño se prolonga, de alguna manera, en los diversos análisis interpretativos del fenómeno dentro del campo historiográfico contemporáneo.

\section{BLASFEMIAS VERSUS ATEÍSMO: EL DEBATE HISTORIOGRÁFICO}

Tema tradicionalmente polémico, sus diferentes interpretaciones suscitan enconadas controversias entre los investigadores de la historia de la cultura religiosa europea. Diversas tomas de posición teórica se articulan dentro del panorama historiográfico continental. A este respecto, en 1948, Johan Huizinga no dudaba en afirmar que la blasfemia era un «pecado estúpido que no puede surgir más que de una fe profunda» ${ }^{2}$, juicio compartido por Maureen Flynn ${ }^{3}$ y Alain Cabantous ${ }^{4}$ cuando argumentan que los delitos verbales traducen un estado de íntima familiaridad con la doctrina católica, un reconocimiento profundo de su autoridad que no deja lugar al escepticismo religioso. Idéntica opinión expresada por el historiador Jesús María Usunáriz en su

\footnotetext{
${ }^{1}$ Este trabajo es fruto de una investigación más amplia beneficiaria de una beca postdoctoral financiada por la Secretaria de Estado de Universidades e Investigación del Ministerio de Educación y Ciencia (EX20040257), realizada en la École des Hautes Études en Sciences Sociales de París (EHESS), Centre de Recherches Historiques, Groupe d'Études Hispaniques, dirigida por el profesor Bernard Vincent.

2 Huizinga 1948, 74.

3 Flynn 1995, 29-36.

4 Cabantous 1998, 184.
} 
estudio sobre los procesos por blasfemia del tribunal inquisitorial de Logroño ${ }^{5}$. Por el contrario, Jean Delumeau ${ }^{6}$ y John Sommerville ${ }^{7}$ manifiestan una posición radicalmente opuesta cuando afirman que las expresiones blasfemas son marcas reveladoras de la escasa o insuficiente cristianización de la mayoría de la población europea occidental en los albores de la Edad Moderna, manifestación embrionaria de un naciente ateísmo. Estas dos actitudes tan diametralmente contrarias denotan lo muy ambiguo y contradictorio que puede llegar a resultar la terminología según los criterios interpretativos del historiador de turno. En torno a este debate, Robert Muchembled se sitúa en una posición intermedia ${ }^{8}$. Piensa que el blasfemo, en realidad, no representa, ni es un marcador fiable del vigor de la fe cristiana, ni tampoco una señal inequívoca de la debilidad del cristianismo. Opina que para comprender el fenómeno en toda su complejidad es imprescindible incrustar el concepto de blasfemia dentro de los comportamientos cotidianos de la gente ordinaria de antaño.

La controversia trasciende el simple marco historiográfico cuando ciertos eruditos argumentan que las blasfemias son parte inherente de la misma naturaleza del cristianismo. El filósofo canadiense Charles Taylor sostiene que la blasfemia es una manifestación transgresora verbal intrínseca a la religión cristiana, componente íntima de una realidad espiritual que se configura en el imaginario social del cristianismo: «El blasfemo no es tolerable más que en un sistema de pensamiento cristiano o post-cristiano, que tiene en el horizonte mental el recuerdo de Cristo recibiendo blasfemias durante la Pasión; esta aceptación del sufrimiento de Dios y por el mismo Dios es inexportable al Islam, excepto por un proselitismo indirecto rechazado por los musulmanes» ${ }^{9}$. En una dirección parecida se manifiesta el investigador catalán Juan J. Vinyoles cuando afirma que la tolerancia hacia el ultraje verbal del catolicismo es una característica cultural de una religión monoteísta tibia -impensable en los rigorismos judío, protestante o islámico ${ }^{10}$.

La experiencia demuestra cómo la blasfemia es inseparable muchas veces del resto de comportamientos religiosos de una colectividad, en este caso de tipo piadoso. Un grupo humano rinde homenaje a Cristo o su santa Madre con una fervorosa devoción acompañada de los más groseros exabruptos ${ }^{11}$. Una línea de pensamiento que entronca con uno de los ejes vertebradores sobre los que se asienta el marco de valores culturales de buena parte de los europeos de generaciones pasadas, idea expresada por el antropólogo Manuel Delgado Ruiz cuando opina que la blasfemia es

${ }^{5}$ Usunáriz 2006, 207.

${ }^{6}$ Delumeau 1978, 522.

${ }^{7}$ Sommerville 1990, 78-94.

${ }^{8}$ Muchembled 1988, 76-77.

9 Taylor 1989, 121.

${ }^{10}$ Vinyoles 1983, 99-110.

${ }^{11}$ Manuel Delgado Ruiz aporta el ejemplo acaecido en un pequeño pueblo de Lugo a fines de los años ochenta del pasado siglo cuando los cofrades de la parroquia llevaban en andas la imagen de la santa patrona del lugar en peregrinación. Agotados por el esfuerzo y la dificultad en transportar la sagrada estatua a causa de lo abrupto del camino, no titubeo uno de los cofrades en exclamar: «Me cago en Dios, que se cae la Virgen» (Delgado Ruíz 1989, 511). 
un aspecto esencial del patrimonio masculinolectal de la cultura occidental cristiana, una práctica verbalizadora de los varones de la que están excluidas las mujeres, un componente substancial para la adquisición de una personalidad masculina por parte de los jóvenes con un valor casi iniciático ${ }^{12}$. Según esta interpretación, el insulto blasfematorio se inscribe en el corazón de la diferenciación simbólica de los sexos.

Según estos razonamientos, la blasfemia sería un elemento integrante de la cultura oral del hombre común europeo, sin que ello implique, necesariamente, descreimiento religioso. Ahora bien, ¿La blasfemia tiende puentes directos con la incredulidad religiosa? ¿Puede hablarse de la presencia de verdaderos ateos en la Europa preindustrial? Los historiadores exteriorizan diversos posicionamientos teóricos.

El historiador francés Emmanuel Le Roy Ladurie sugiere la posibilidad de la existencia de ateístas en la Europa de la Baja Edad Media. En su magistral estudio sobre la aldea occitana de Montaillou aporta preciosos ejemplos de increencia campesina en la Francia meridional del siglo XIV ${ }^{13}$. De su lado, Jean-Claude Schmitt cree en la probable existencia de un minoritario ateísmo popular medieval, muy distinto del escepticismo religioso de la era contemporánea. Argumenta que en las fuentes documentales de los siglos XII-XV se encuentran abundantes ejemplos de acontecimientos extraordinarios que la extrema credulidad de la gente sencilla atribuye automáticamente sin pensar a fenómenos milagrosos, aunque también observa una cierta inquietud y desconfianza que lleva a ciertas personas a expresar conductas escépticas y a demandar pruebas consistentes para reconocer la veracidad del milagro ${ }^{14}$. En esta misma línea se posiciona el historiador británico Keith Thomas cuando opina que no debe subestimarse la importancia de un cierto escepticismo religioso popular en la Europa medieval. Cree probable que el fenómeno haya podido tener más relevancia de lo que en principio se pudiera pensar ${ }^{15}$.

Bien al contrario, historiadores como Febvre ${ }^{16}$ y Mollat ${ }^{17}$ piensan que no puede hablarse de «increencia» en Europa durante la Edad Media y el siglo XVI. Según sus argumentaciones, el término debe emplearse con suma cautela cuando se habla del marco cultural religioso en el que viven inmersos la mayoría de europeos de la época preindustrial, dominado por una religiosidad impregnada de fuerte contenido supersticioso con una marcada tendencia a la credulidad extrema en las explicaciones de los milagros y los prodigios cuando no se comprende la naturaleza de los acontecimientos $^{18}$. Habrá que esperar hasta la década de $1640,-$ tras un lento periodo de interiorización intelectual de pensamiento racionalista por parte de un sector de la élite cultural-, para ver surgir en Europa corrientes de verdadero escepticismo religioso. Una interpretación que da pie a conjeturar sobre la hipótesis de la existencia en

\footnotetext{
12 Delgado Ruíz 1989, 510.

13 Le Roy Ladurie 1975.

14 Schmtt 1993, 126-140.

15 Thomas 1971, 199-200.

16 Febvre 1947.

17 Mollat 1982.

18 Sobre la diferentes definiciones del concepto de creencia ver Wirth 1983, 298-315.
} 
la península ibérica de un pensamiento libertino por parte de un segmento de la élite social española ${ }^{19}$. Otra prueba presentada por Febvre para rechazar la existencia de un pensamiento ateísta anterior al siglo XVII se fundamenta en la inexistencia de un proyecto filosófico y científico construido sobre bases exclusivamente materialistas, algo inconcebible en la cultura europea medieval y moderna, cimentada en un orden de ideas donde ciencia y magia, sagrado y profano, religioso y pagano, se encuentran íntimamente entrelazadas. La noción de naturaleza como un ente autónomo con sus propias leyes deterministas de funcionamiento no existe. Según sus consideraciones, en el viejo continente el «ateísmo» intelectual se consolidará en el transcurso del siglo XVIII.

Otros historiadores modernistas expresan opiniones radicalmente divergentes. François Berriot discrepa de la hipótesis de Febvre cuando afirma que la increencia está ya presente en la Francia del siglo XVI, originada por la eclosión cultural del Renacimiento, la división del cristianismo entre católicos y protestantes, y por la crisis que atravesaba entonces la sociedad occidental (comercio, industria y agricultura se transforman, ascenso de la burguesía, centralización de la monarquía, luchas sociales, espíritu del capitalismo imponiéndose a la caridad cristiana). Estas transformaciones tan brutales causan un miedo social generalizado y unas repercusiones enormes: blasfemias, sacrilegios, brujería, abortos, infanticidios, suicidios, etc. Berriot encuentra difícil imaginar que entre las clases populares de las ciudades y pueblos no existieran hombres de sentimientos antirreligiosos, hostiles a los ministros de la Iglesia y de naturaleza agresiva frente a las cosas sagradas, una irreligiosidad de instintos primarios donde está ausente la reflexión racionalista del ateísmo ilustrado ${ }^{20}$. Le Roy Ladurie se añade al coro de las voces críticas cuando afirma que negar la hipótesis de cualquier atisbo de incredulidad religiosa en la Europa medieval y renacentista implica partir de un análisis metodológico erróneo, inadecuado para el estudio de la increencia medieval y renacentista al aplicar a estos siglos de la historia europea los criterios racionalistas del ateísmo contemporáneo, heredero del Siglo de las Luces.

Esta disparidad de interpretaciones parte de la raíz interpretativa que los diversos historiadores han otorgado al concepto de «ateísmo». La palabra «ateo», por si misma, entraña una gran dificultad de definición. Posiblemente, la mejor exposición del problema la haya plasmado Lucien Febvre en su admirable estudio sobre la increencia en la Europa del siglo XVI. Señala este historiador galo que el término «ateo» era entonces una injuria utilizada para designar a un herético, un cismático, un

\footnotetext{
19 Jesús Villanueva en un interesante artículo cree en la probable existencia de un libertinismo social en la España del siglo XVII. Este grupo de libertinos españoles se aglutinaría en la Corte de Madrid en el período de gobierno del Conde Duque de Olivares (1621-1643) en unos años donde se abrían importantes expectativas de apertura intelectual suscitadas por la ascensión política del nuevo válido del monarca Felipe IV. El nuevo clima social habría generado entre un reducido número de intelectuales inquietudes importantes sobre la verdadera función de la religión católica en la vida cotidiana de los españoles y el papel histórico de España en el mundo. Una reflexión que les llevaría al desencanto y a posicionarse en una intransigencia ideológica cada vez más radical (Villanueva 2005, 85-103.).

${ }^{20}$ Berriot 1986.
} 
heterodoxo y, en general, a toda persona que no compartiese la fe de la comunidad a la que pertenecía. Febvre añade que todas las terminologías destinadas a calificar las diversas formas de increencia fueron elaboradas después del siglo XVI: libertino y libertinaje (hacia 1600); deísmos (siglo XVII); panteísmo, materialismo, naturalismo, fatalismo, librepensador (siglo XVIII); racionalismo (siglo XIX). Por esta razón, la gente del siglo XVI no poseía ni los conceptos, ni la capacidad de abstracción mental necesaria para entender la naturaleza del vocablo ${ }^{21}$. Por su parte, Julio Caro Baroja dice que las voces «ateísmo», «ateísta» y «ateo» están incrustadas en el vocabulario castellano desde finales del siglo XVI, extendiéndose su uso a lo largo de la primera mitad del XVII 22 . Fray Luís de Granada ya emplea la palabra «ateísta» en su tratado Del símbolo de la fe, publicado en 1582, cuando habla de la «cura de los ateístas epicúreos que atribuyen toda lo criado al acaso» ${ }^{23}$.

\section{TEOLOGÍA MORAL Y ATEÍSMO}

El clero asociaba siempre la palabra impía a un signo de increencia. La blasfemia era una puerta que conducía a la impiedad e incluso al ateísmo más irredimible. Teológicamente era un pecado de infidelidad (infidelitas) a Dios por oponerse a la virtud teologal de la confesión de la fe y encerrar el germen herético de la incredulidad religiosa y el deicidio ${ }^{24}$. Toda manifestación de contenido ateísta era condenada por la Iglesia desde todos los puntos de vista. No obstante, la teología moral diferenciaba el ateísmo de origen filosófico-naturalista docto, del popular, producido por la desesperanza $^{25}$. Resulta inapropiado calificar de ateístas o de incrédulos a la gente sencilla que profería blasfemias contra la majestad divina. Es más conveniente definirlos como individuos que manifiestan temporalmente su malestar emocional a través de la disidencia religiosa cuando se enfrentan a circunstancias difíciles. La gran mayoría de las palabras blasfemas pronunciadas por la gente ordinaria tienen su origen en el mal hábito, en los trastornos de las conciencias causados por la excitación del juego, la ingesta de alcohol o las chanzas festivas, en las alteraciones psicológicas de las conductas provocadas por las contrariedades de la vida o en las frecuentes bregas y peleas violentas que se producían a menudo entre familias y vecinos ${ }^{26}$. Las blasfemias son, fundamentalmente, la expresión de una sublevación verbal de protesta ante las injusti-

\footnotetext{
${ }^{21}$ Kristeller 1975, 337-348.

22 Caro Baroja 1974, 229-288; 1985, 189-211 y 213-223.

${ }^{23}$ La doctrina filosófica de los atomistas griegos, desarrollada posteriormente por Epicuro y ciertos textos de autores aristotélicos, sostiene como axioma la negación de la inmortalidad del alma. Baroja señala que se podía llegar al ateísmo por la vía de las lecturas de determinadas obras filosóficas de la Antigüedad clásica. El antropólogo vasco cita un ejemplo de un hombre que fue a denunciarse a la Inquisición portuguesa confesando su descreencia de la fe cristiana tras leer diversos libros (Caro Baroja 1985, 215-217).

${ }^{24}$ Todavía en el siglo XVIII prelados rigoristas como el francés Jean Baillat acusaba a los blasfemadores de ser deicidas.

${ }^{25}$ Caro Baroja 1985, 219.

${ }^{26}$ Schwart 2010, 42-43.
} 
cias de la vida ${ }^{27}$. Una manifestación del sistema de inversión jerárquico-social característico del espíritu popular expresado en los momentos de peligro o desazón, especie de transformación «carnavalesca» del lenguaje religioso oficial ${ }^{28}$. Dios y los demás personajes sagrados son envilecidos y degradados en el plano religioso, desposeídos de sus atributos divinos y convertidos en chivos expiatorios de los padecimientos humanos. La blasfemia expresaría una negación «momentánea» del poder de $\operatorname{Dios}^{29}$. Sobre esta cuestión el lingüista francés Emile Benveniste, en un importante artículo, precisa una de las características fundamentales del juramento blasfemo:

Es una profanación al orden sagrado del lenguaje. El léxico del juramento o, si se lo prefiere, el repertorio de las locuciones blasfemas, toma su origen y encuentra su unidad en una característica: procede de la necesidad de quebrantar la prohibición bíblica de pronunciar el nombre de Dios (...). Se blasfema en el «nombre» de Dios, porque todo lo que se sabe de Dios es su nombre. sólo por este procedimiento el hombre puede relacionarse con él, para conmoverlo o para herirlo ${ }^{30}$.

¿La exasperación humana ante las continuas adversidades de la vida podía conducir a un ateísmo popular verdadero, no coyuntural? No puede descartarse en absoluto la presencia de formas ateístas simples entre personas anímicamente agobiadas por situaciones frecuentes de extrema frustración. El problema principal radica en separar las expresiones de impiedad religiosa pronunciadas sin pensar en los momentos de acaloramiento emocional, de aquellas otras proferidas con expreso convencimiento de su perversidad. No obstante, la incredulidad religiosa popular difícilmente puede calificarse de «atea» en el sentido erudito del término, aunque tampoco puede excluirse la existencia de un escepticismo religioso latente en una pequeña franja social de la cultura popular ${ }^{31}$. En España hay abundantes ejemplos de personas procesadas por la Inquisición que expresan una clara sensibilidad irreligiosa y anticlerical al negar la inmortalidad del alma, la resurrección de los cuerpos y la esperanza de una vida futura después de la muerte, pero como muy bien indica Francisco Bethencourt, las estadísticas no permiten distinguir la parte de ateísmo real contenido en las blasfemias heréticas ${ }^{32}$. Ignoramos si detrás de las expresiones ateas había simplemente rabia o maldad, no hay modo de saber si la irreligión tenía plaza asentada en la mente de muchos católicos.

¿Existía una tradición blasfematoria atea, urbana o rural, en Cataluña? La pregunta no tiene contestación. Los documentos judiciales no desvelan en muchos casos la verdadera naturaleza de las creencias religiosas de los encausados. En los resúmenes procesales consignados en las Relaciones de causas de fe del tribunal de Barcelona

${ }^{27}$ Dedieu 1981, 208-230.

${ }^{28}$ Bakntin 1974, 124.

${ }^{29}$ Cabantous 1998, 192.

30 Benveniste 1974, 252.

31 Minois 1998, 96.

32 Bethencourt 1998, 332-334 y 336-339. 
no se registran, de modo regular, las preguntas que los inquisidores dirigían a los reos para conocer sus niveles de cultura y práctica religiosa (dogmas fundamentales de fe, rezos obligatorios, frecuencia en recibir los sacramentos) hasta bien entrado el siglo $\mathrm{XVII}^{33}$. En los procesos inquisitoriales y sermones doctrinales contra la blasfemia predicados en la Cataluña moderna no se denuncian casos de ateos convencidos, sí de escépticos y obstinados en no participar de la ceremonia de la misa ni de los sacramentos de la Iglesia, ${ }^{34}$ por contra, son muchos los cristianos piadosos que pierden el timón de la cordura y empiezan a blasfemar como herejes poseídos por el diablo cuando se tuercen un poco las cosas para sus intereses. Una plática misional escriturada a principios del siglo XVIII lo verifica:

Molts christians que adoran aquest nom SSmm. y veneran sa preciosisima sang, ab una mica de impaciencia la esmenuran como si fos cos, y sanch de una bestia; si ara los cau, pel cami, sil matxo si la mula nols va be, si la criada no torna aviat, ja qualsevol coseta a Deu, caps de Deu, votos a Christo, sagnats, y coronats, que fan erizar los cabells; aixis sels posam entre els peus, como si fos la sang de la plaça ${ }^{35}$.

En las causas procesales por delitos de blasfemias escrituradas por el tribunal inquisitorial de Barcelona a lo largo de su historia se describen los rasgos fundamentales del blasfemo convicto: persona de sexo masculino, perteneciente a las categorías sociales de la cultura popular (artesano, campesino, pastor...), emocionalmente inestable, especialmente sensible frente a las situaciones de inseguridad y peligro de la vida cotidiana, y cuya válvula de escape a su agresividad latente, son, frecuentemente, los insultos personales acompañados de blasfemias bajo los influjos del desánimo, la ira, la embriaguez provocada por la ingesta de alcohol, el juego o simplemente al hábito de la costumbre. La mayoría han proferido blasfemias y juramentos sin verdadera intención de ofender deliberadamente a Dios ${ }^{36}$.

No obstante, de la lectura de algunas causas judiciales pueden inferirse claras conductas irreligiosas por las resistencias populares a la aplicación de castigos morales por haber blasfemado. En 1638, Pau Finat, de 45 años, originario de la población de Montblanch en el obispado de Solsona, denunciado por renegar de Dios de manera pública y mantener tozudamente su actitud, agravó su cargo de inculpación

${ }^{33}$ AHN. INQ, (Archivo Histórico Nacional. Inquisición), Relaciones de causas de fe, Libros 730, 731, $732,733,734,735$. Las fuentes documentales y la bibliografía antigua empleadas en la elaboración del trabajo están referenciadas en el listado final bibliográfico.

${ }^{34}$ Kamen 1998, 86.

35 «Muchos cristianos que adoran este nombre Santísimo, y veneran su preciosísima sangre, con un poco de impaciencia lo desmenuzan como si fuese cuerpo, y sangre de una bestia; si ahora les cae, por el camino, si el macho, si la mula no les va bien, si la criada no vuelve pronto, ya cualquier cosita a Dios, cabezas de Dios, votos a Cristo, sangrados, y coronados, que hacen erizar los cabellos, así se los ponen entre los pies, como si fuese la sangre de la plaza» (BUB (Biblioteca Universitaria de Barcelona), Anónimo, Plática de misión, Ms. 894 , sin numerar).

${ }^{36}$ Gelabertó, 651-676. 
al rechazar besar el suelo en el lugar donde poco antes había pronunciado la injuria divina a instancias de los testigos -siguiendo las instrucciones de la literatura moral eclesiástica-, si no se le obligaba a la fuerza ${ }^{37}$. Otros dan un paso más al frente con el añadido de burlas al clero y a los sacramentos. En el Auto de Fe celebrado en la plaza del Born de Barcelona a 12 de agosto de 1565 salió Antich Marquès, un campesino natural de la Seo de Urgel, condenado a abjurar de levi por decir blasfemias heréticas, añadido a las penas accesorias de pagar una multa de treinta ducados, oír misa todos los domingos y fiestas de precepto con la obligación de confesar y comulgar en las tres Pascuas del año, ya que el tribunal le aplicó la agravante de su absentismo habitual a los oficios religiosos y su terquedad en rechazar la práctica regular de los sacramentos desde hacia más de diez años por considerarla algo inútil ${ }^{38}$. Disponemos de más información sobre el juicio a Philippe Leonard, un campesino habitante en Tarragona, natural de la localidad francesa de Agullon, cerca de Burdeos, 46 años de edad en 1637, quien presumía sin pudor de no haber confesado desde hacia más de veinte años y que nadie podía obligarle a escuchar misa ni sermón. Renegaba y blasfemaba a cada instante: «Por la cabeza de Dios», y decía que el diablo le ayudaba pese a saber que su alma se quemaría en el infierno. Pregonaba a voces su odio al clero y a los predicadores misioneros diciendo que llevaban la discordia en los lugares donde predicaban, incitaba a los fieles a desertar de las iglesias y no hacer caso de las arengas apostólicas de los sacerdotes cuando clamaban a los cristianos viniesen a confesar para serles perdonados los pecados. Estas convicciones no las mantuvo frente a los jueces inquisidores. Su causa fue suspendida ${ }^{39}$.

Hay indicadores que invitan a la reflexión acerca del estado de ánimo con que el pueblo acogía la llegada de los predicadores apostólicos en la Cataluña rural de los siglos XVII-XVIII. Las blasfemias y las expresiones de menosprecio dirigidas a los ministros de Dios revelan en ocasiones un fuerte sentimiento anticlerical ${ }^{40}$. A veces desempeñar las labores educativas cristianas no era una tarea fácil. En un manuscrito redactado en 1777 donde se recopilan los hechos más sobresalientes acaecidos en el transcurso de las misiones evangelizadores de los monjes franciscanos del Colegio Seminario de Escornalbou (Tarragona) ${ }^{41}$-desde su fundación en 1686 hasta su extinción en 1835- los frailes lamentan tener que escuchar frases despectivas como: «Tiempo avra para confesar, que acaso somos hereges en este villa, para que nos

37 AHN. INQ, Relaciones de causas de fe, Libro 734, Fol. 304.

38 Ibídem, Libro 730, Fol. 68.

${ }^{39}$ Ibídem, Libro 734, Fols. 83-84.

40 Cabantous 1998, 190.

${ }^{41}$ Localidad situada en el interior de la provincia de Tarragona. El monasterio medieval ubicado en aquella población acogía el mayor y más importante centro misionero franciscano de la Cataluña de fines del siglo XVII hasta su exclaustración en 1835. La actividad pastoral de los religiosos de la orden de San Francisco se extendía más allá de las fronteras diocesanas de la Archidiócesis tarraconense. Su acción misionera se prolongaba a las comarcas septentrionales de Castellón y Teruel, enmarcadas en la diócesis de Tortosa; a buena parte de las tierras más orientales de Huesca, bajo jurisdicción episcopal de Lérida; sin olvidar el obispado de Elna, en el Rosellón, territorio incorporado a la administración francesa tras la firma del Tratado de los Pirineos en 1659. (Ver Borras Galceran 1993, 93-114). 
aya de venir esse padre con tanto griterío del infierno» ${ }^{42}$. Hablan de lugareños que se niegan obstinadamente a asistir a los oficios de la misión y mueren sin recibir la unción sacramental y el Viático; otros les acusan de ser personas malas, de asustar y alborotar al pueblo con sus sermones, de enseñar a la gente a pecar en lugar de apacentarla; muchos explican su ausencia de las ceremonias de la misión por vivir alejados de la parroquia y no interesarles lo más mínimo sus prédicas; numerosos campesinos dicen que prefieren no descuidar las faenas agrícolas del campo; algunos simplemente argumentan que no les apetece nada oír los desengaños del predicador de turno ${ }^{43}$. Los misioneros soportaban el desprecio burlón de algunos vecinos. En el año 1713, el franciscano Isidro Febrer encabezaba un grupo de religiosos de su orden en camino a una localidad de la comarca del Alt Empordà, en el obispado de Gerona, cuando al pasar cerca de una viña en el término de Cadaqués, en el litoral norte gerundense, vieron a un payés trabajando en unos viñedos. Percatado de su presencia, dejo sus enseres agrícolas y se puso a increparlos chillando, obsequiándoles los oídos con un juego burlesco de palabras: «Frare, vol dir frau, frau vol dir engany, engany vol dir folgat i desgraciat» («Fraile significa fraude, fraude significa engaño, engaño significa vago y desgraciado» $)^{44}$. En ocasiones el gesto despreciativo procedía incluso de la máxima autoridad municipal. En 1729, el Batlle ${ }^{45}$ de una parroquia del obispado de Tortosa se ausentó de la localidad mientras duraron las jornadas misioneras ${ }^{46}$. No obstante, los insultos y desprecios dedicados al clero podían tener a menudo unos orígenes bien distintos a los religiosos: animadversión personal, pleitos económicos o fiscales, etc. ${ }^{47}$. Un anticlericalismo primario expresado a través del lenguaje blasfematorio.

Hasta hace pocas décadas todavía se oía en el campo catalán la frase: «Any de missió, any de maledicció» («Año de misión, año de maldición»). Diversos memoriales de clérigos dirigidos a sus obispos o a los superiores de sus respectivas órdenes hacen pensar con fundamento que esta locución encubriría un proceder antirreligioso compartido por cierto número de personas. Los sermones de los predicadores dedicados al trabajo evangelizador en el interior de Cataluña condenan la formulación simplista arraigada en la opinión popular de atribuir los años de malas cosechas y desventuras al hecho de haber misionado en la población. Esta opinión es invertida por la Iglesia: la impiedad religiosa conduce inexorablemente a la punición divina en forma de enfermedades, esterilidad de la tierra, catástrofes meteorológicas, etc. A fines del siglo XVII el dominico Tomás Pinell predicaba sobre este asunto:

\footnotetext{
42 APFC (Archivo de los Padres Franciscanos de Cataluña), Libro verde de la fundación del Colegio Seminario de Escornalbou de los casos raros de las Missiones y de las vidas de algunos venerables misioneros de dicho colegio, y de la serie de los guardines, 1777, Manuscrito sin numerar.

43 APFC, Sermones misionales, Manuscrito sin numerar.

${ }^{44}$ Libro verde de la fundación del Colegio Seminario de Escornalbou...op. cit.

${ }^{45} \mathrm{El}$ alcalde, nombrado por cualquier instancia (el rey, el señor, el obispo) que tuviera bajo su control la jurisdicción territorial.

${ }^{46}$ Libro verde de la fundación del Colegio Seminario de Escornalbou...op. cit.

47 Cabantous 1998, 191.
} 
Veus aquí la causa, malaltias, malas cullitas, de las desgracias que se segueixen tal vegada a una Missió, y perque diuhen alguns be que sense raho: Any de Missió, any de maledicció. Donan la culpa a la missió, si hi ha malaltias, mala collita, y no la tenen ells sino la culpa es per lo despreci, que fan de la missió, no confessen, nis converteixen, y perço los castiga $\mathrm{Deu}^{48}$.

Por los mismos años, otro predicador de la orden de Santo Domingo preguntaba en su exposición oratoria la causa del rencor religioso de ciertos cristianos, insensibles al mensaje redentor de los ministros de Cristo:

Si es tan poderosa y eficaz la paraula de Deu, si es un foch, un martell, una espasa, una antorxa, com es que en molts y moltes obra tan poch, nols converteix, ni encen, ni penetra, ni illumina lo enteniment? No hi ha predicas, ni sermons, ni exhortacions, ni avisos, ni inspiracions, se quedan tan durs com sempre, com al principi y fi de la missió ${ }^{49}$.

La etimología de los apodos y motes familiares es una preciosa fuente, aún poco estudiada, que permite conocer los sentimientos de afecto o desafección de la cultura popular rural ante la religión. Tradicionalmente la gente de muchos pueblos se reconoce entre sí, no por sus apellidos, sino por su apodo o mote, heredado de sus progenitores o antepasados. Los hay de todo tipo: relacionados con lugares geográficos, actividades profesionales, características físicas y fisonómicas, etc., calificación léxica que permanece en la memoria colectiva familiar y comunitaria a través de infinitas generaciones. Rasgo distintivo que a veces se arrastra fatídicamente como un estigma verbal impuesto para siempre como signo identitario. Cuando el apodo tiene una connotación peyorativa cumple una función represora estigmatizante de infamia pública, una advertencia directa dirigida al resto de la comunidad que prohíbe transgredir las normas sociales seculares, si no se quiere cargar con la lacra de un apodo humillante transmitido indefinidamente de padres a hijos. Una mancha infamante que marca a todos los miembros de la familia. La diversidad de sensibilidades del mundo rural tradicional frente a lo religioso, la convivencia de creyentes y de escépticos, de gente piadosa y de ateos, de clérigos y laicos, se desvela en parte a través del análisis filológico de los apodos. Veamos un caso particular. La parroquia de El Prat de Llobregat, situada a escasos kilómetros de Barcelona, posee un rico repertorio de mals noms (apodos), muchos de ellos de origen antiquísimo y que revela la divergente opi-

\footnotetext{
48 «Ved aquí la causa, enfermedades, malas cosechas, de las desgracias que se siguen tal vez a una misión, y porque dicen algunos bien sin razón: Año de misión, año de maldición. Dan la culpa a la misión, si hay enfermedades, mala cosecha, y no la tienen ellos sino la culpa es por el desprecio, que hacen de la misión, no confiesan, ni se convierten, y por esto los castiga Dios» (BUB, Sermó de missió, Ms. 693. Sin numerar).

49 «Si es tan poderosa y eficaz la palabra de Dios, si es un fuego, un martillo, una espada, una antorcha, como es que en muchos y muchas obra tan poco, no los convierte, ni enciende, ni penetra, ni ilumina el entendimiento. No hay prédicas, ni sermones, ni exhortaciones, ni avisos, ni inspiraciones, se quedan tan duros como siempre, como al principio y fin de la misión» (BUB, Sermón misional, Ms. 694. Sin numerar).
} 
nión que las personas otorgaban a la religión. Los hay manifiestamente piadosos con denominaciones angélicas: Ca l'Angel, Cal Serafi'; otros descubren una viva práctica religiosa: Cal Missaire, Cal Misses, Cal Monjo, Cal Pau de les Misses, Cal Rectoret; algunos, sin embargo, son inequívocamente irreligiosos. Cal Caga Deus, Cal Caga Hosties, Cal Dimoni ${ }^{50}$. En todos ellos no deja de esconderse un cierto tono de burla soterrada. ¿La atribución de estos mals noms a las familias es fruto de la actitud de individuos aislados o de comportamientos prolongados en el tiempo? Una vez más la cuestión queda sin respuesta.

Por lo general, la censura eclesiástica se dirige básicamente hacia ciertos grupos sociales tradicionalmente desafectos de los asuntos religiosos, gente con fama de camorrista, entregada a oficios de baja estofa o a la más vil de las delincuencias. Blasfemias y juramentos estaban extendidos entre todas las clases sociales, no obstante, existían «profesionales» de la blasfemia, por llamarlos de alguna manera, que escandalizaban constantemente los oídos de las personas devotas, no acostumbradas a oír recitar toda una letanía de insultos sacrílegos. Las autoridades asociaban a determinados colectivos humanos provenientes del submundo de la marginación (vagabundos, bandoleros, gitanos, prostitutas...) y a ciertos oficios con las expresiones más impúdicas del lenguaje blasfemo.

En la Europa preindustrial ciertas profesiones eran asociadas al vicio de blasfemar. Las maldiciones y las injurias blasfemas más soeces solían salir frecuentemente de la boca de dos colectivos profesionales: los marineros y militares ${ }^{51}$. Normalmente la gente empleada en el oficio del mar estaba endurecida por el clima violento de la profesión. Los insultos sacrílegos eran habitualmente pronunciados en el transcurso de las actividades corrientes de la navegación. Los altercados cotidianos entre marineros con frecuentes peleas, la presión jerárquica de un régimen disciplinario implacable destinado a abortar cualquier intento de sedición a bordo acompañado a menudo de castigos corporales, la ingestión descontrolada de alcohol, explican la extensión de la blasfemia entre los tripulantes de los navíos ${ }^{52}$. Sorprendentemente, la literatura religiosa de reforma moral manuscrita o impresa elaborada en Cataluña durante el período moderno no condena el lenguaje blasfemo de los marineros en un territorio en que la actividad marítima era muy importante para el sector económico y comercial. ¿Estamos, quizás, confrontados a un problema de fuentes por la excesiva «especialización» del clero del Principado en reevangelizar el campo catalán? ¿Era prioritario en la política pastoral de los obispos erradicar las blasfemias del medio rural antes que las marítimas? De su parte, la Inquisición de Barcelona tampoco se ocupó de reprimir a los marinos blasfemos, sólo se registra un procedimiento judicial por este delito ${ }^{53}$. Bien distinto es el panorama por lo que respecta al oficio de la milicia.

\footnotetext{
50 Palma de Mallorca 1958, 381.

51 Cabantous 1998, 89.

52 Cabantous 1990, 282.287.

${ }^{53}$ En 1725, al marinero habitante en Barcelona Gaspar Tarrida le fue abierta causa judicial por decir blasfemias. Se desconoce la sentencia (AHN. INQ, Legajo 2170).
} 
Los soldados, generalmente mercenarios, gente de baja estofa social, ordinariamente de poca cultura, sin escrúpulos ni remordimientos, entregados a la incesante búsqueda del botín fácil y a quienes no les importaba un ápice venderse al mejor postor a costa de la peor de las traiciones, era un colectivo que tradicionalmente profería blasfemias sin mostrar el menor rescoldo de culpabilidad ${ }^{54}$. A fines del siglo XVII el jurisconsulto Francisco de Amaya calificaba a los militares españoles de «banda de libertinos, mezquinos, crueles, lujuriosos, piratas, ladrones, perjuros y blasfemadores ${ }^{55}$. Con este material humano las buenas palabras no bastaban para imponer la disciplina militar y religiosa. En el siglo XVIII y comienzos del XIX se dictaron distintas leyes para reprimir a los blasfemos en las filas del ejército ${ }^{56}$.

El brazo judicial del Santo Oficio prolongaba su acción hacia aquellos representantes del ejército cuyo comportamiento despertara sospechas de increencia ateísta. El soldado de 30 años, Juan Díaz, originario de Santillana, en el obispado de Burgos, destinado en 1584 en el castillo de Perpiñán, tenía la mala costumbre de jurar mientras jugaba: «Pese a Dios», «Cabeza de Dios», «Por vida de Dios». Estos actos maledicentes se agravaron al acompañarse de insultos dirigidos a una imagen de la Virgen que se hallaba colocada en una hornacina del muro de la entrada principal de la fortaleza militar. El reo, airado, se encaró con la figura esculpida de la madre de Cristo diciendo: «Por esta bujarrona ${ }^{57}$ no gano yo ningún día», «Nunca puedo ganar delante de esta jodida imagen, o desta diablo de imagen». El tribunal de la Inquisición de Barcelona no aplicó ninguna eximente de irresponsabilidad a la hora de dictar sentencia, visto que se trataba de una persona con extensos antecedentes de público blasfemador. Se le condenó a oír una misa vestido con el sambenito de penitente de blasfemo, abjuración de levi, cien azotes a recibir por las calles de la capital del Rosellón y cinco años de destierro ${ }^{58}$.

A este respecto, los soldados del importante destacamento militar de Perpiñán no sobresalían especialmente por sus buenas costumbres religiosas. Muy a menudo estaban envueltos en altercados públicos, estupros, robos, junto a una indiferencia o

${ }^{54}$ Cabantous 1998, 89-92.

55 Quatrefages 1978, 542.

${ }^{56}$ El tratado V de las Ordenanzas de la Armada de 1748 impone al soldado blasfemo la pena de serle atravesada la lengua con un hierro candente. Cruel castigo que reaparece en el título X del tratado VIII de las ordenanzas militares de 1768 a los que se añadieron el descuartizamiento para el sacrílego, el corte de mano para el que golpeara a un oficial y el ahorcamiento por desobediencia ante el enemigo o la sedición. Castigos todos ellos inspirados en la legislación antigua de la Novísima Recopilación. En 1802, una nueva Ordenanza suprimió definitivamente la pena de muerte para los marineros y soldados blasfemos pero se mantuvieron las penas corporales. La Real Orden disponía para el blasfemo la pena de recibir de doce a veinte palos, privación de vino por uno o dos meses y con destino de limpieza en la proa de la nave. Si reincidiese se le pondría una mordaza en la boca durante un tiempo máximo de una hora en un lugar visible del buque o cuartel. En los casos graves se le azotaría hasta sesenta veces si fuera marinero o recibiría cuatro golpes de baquetas si era soldado. En la práctica las penas corporales más extremas nunca se aplicaron (Ordenanzas Generales de la Armada: parte primera sobre la gobernación militar y marinera de la armada en general, y uso de sus fuerzas en la mar, Vol. II, Madrid, 1793, Tratado V, Titulo I, 56-57).

${ }^{57}$ Sinónimo de homosexual/lesbiana.

${ }^{58}$ AHN. INQ, Relaciones de causas de fe, Libro 730, Fols. 406-407. 
desprecio de lo religioso que las autoridades episcopales juzgaban escandaloso ${ }^{59}$. En febrero de 1658, Francisco de Burgo, capellán mayor castrense del tercio de caballería con sede en la antigua ciudad catalana, envía un memorial a Ramón de Semmenat, obispo diocesano de Barcelona, informándole del gran absentismo religioso de que hacían gala los militares destinados en aquella plaza defensiva de la frontera norte de la Corona de Aragón, remisos en asistir a la misa dominical, rebeldes en ponerse a los pies del confesionario para ser escuchados en confesión por el sacerdote y recibir la comunión eucarístíca. El 2 de abril del mismo año, el prelado barcelonés publica un edicto por el que se prohíbe admitir en las iglesias a ningún soldado del tercio de Perpinán que previamente no hubiera cumplido con los preceptos eclesiásticos, ordenando a los rectores de la diócesis de Elna -población colindante que ostentaba entonces la capitalidad del obispado- le enviasen la lista de militares alojados en sus parroquias de quienes tuvieran certeza de haber desobedecido el referido mandato, con amenaza de excomunión para los curas desobedientes ${ }^{60}$.

Otros oficios no le iban a la zaga en su menosprecio verbal a los seres celestiales. Entre ellos, taberneros, carreteros y arrieros ${ }^{61}$ destacaban con luz propia dentro de la categoría de los blasfemadores contumaces ${ }^{62}$. Tanto unos como otros se hallaban en perfecta osmosis. Los primeros regentaban los tugurios donde la gente bebía y jugaba hasta la extenuación, lugares de solaz de muchos viajeros en los que se ejercía con total descaro la prostitución más vil. Las tabernas situadas cerca de los caminos eran parada obligatoria para muchas personas que tenían por oficio trajinar con bestias de carga, y entre cuyas paredes solamente se oían reniegos y maldiciones dirigidas al Creador. En los textos escolásticos las tabernas eran lugares siniestros consagrados a la infamia y al pecado, verdaderos «templos del diablo» ${ }^{63}$. Entre los oficios, el de arriero descollaba especialmente por su brutalidad al hablar: «Deu no vulga sino te esclafi» («Dios no lo quiera sino te aplasto»), «Los diablos se men portian, si no me

${ }^{59}$ Los legajos judiciales de la Inquisición de Barcelona registran abundantes casos de militares procesados por blasfemia que recibieron duras condenas.

${ }^{60}$ ADB (Archivo Diocesano de Barcelona), Registra Gratiarum, 1656-1662, Vol. 65. Sin numerar.

${ }^{61}$ A partir de 1458 una disposición municipal de Barcelona imponía a los arrieros de trigo que jurasen por Dios o por la Virgen una pena de un sueldo de multa o un día de prisión (Armenteros Martínez 2002, 987).

${ }^{62}$ En los exempla de la literatura religiosa española de la Edad Moderna aparece retratada la figura depravada del arriero blasfemador justamente castigado por sus pecados: «Alexandro de Faya, escribe, que un gran siervo de Dios, de la Sagrada Religión de la Compañía de Jesús, caminando por España, hizo noche en una venta, a donde halló un arriero que juraba mucho. El buen religioso le rogó que no jurase tanto sin necesidad, y el arriero començo a jurar más, y aunque de ello fue reprehendido, no bastó. Pero vino luego sobre él, el castigo de Dios porque aquella noche, como a la mitad de ella, dentro, y fuera de la venta se oyó tan gran ruido, que puso espanto a quantos estavan en ella, y levantándose, y tomando luzes para ver lo que seria aquella, lo miraron con todo, y hallaron al jurador muerto en la cavalleriza, y a los pies de las bestias. Pusiéronle sobre unas payas y le cubrieron, esperando a la mañana para enterrarlo, pero venido el día, no hallaron el cuerpo, mostrando Nuestro Señor con esto, que ya estava también el alma en el infierno» (J. Caravantes, Pláticas o lecciones muy doctrinales sobre los Evangelios de las Dominicas de todo el año, para desempeño de los padres de almas, y de familias, y aprovechamiento de los que están a su cargo, Barcelona, $1685,252-253)$.

${ }^{63}$ Cabantous 1998, 108-112. 
la pagas» («Los diablos se me lleven, si no me la pagas»). Una profesión, esta última, especialmente denostada por los reformadores del Principado por el maltrato que infringían a los animales cuando blasfemaban. El desorden no se limitaba al espectáculo de ver a un energúmeno de pocas entendederas golpear sin piedad a un pobre caballo o burro, la furia física se extendía a la rabia blasfema ${ }^{64}$, una práctica que según señala Manuel Delgado Ruiz estaría muy enraizada en la cultura rural española en la antigua costumbre generalizada de insultar a los santos como procedimiento eficaz para obligar a trabajar a las bestias del campo ${ }^{65}$.

¿La incredulidad religiosa o las blasfemias son únicamente atribuibles al razonamiento de la lógica popular? ¿Qué peso específico representa la tradición cultural cristiana y las influencias musulmana y judía en la forja de la impiedad religiosa popular?

\section{LAS FUENTES DE LA INCREDULIDAD RELIGIOSA}

\subsection{EL ENEMIGO INTERIOR: EL DIABLO}

Para la Iglesia las blasfemias, juramentos e invocaciones al diablo eran una de las principales fuentes de ateísmo anticristiano. No obstante, las injurias o reniegos dirigidos al demonio no son propiamente, desde el punto de vista jurídico, blasfemias punibles de castigo. La legislación del derecho canónico señala que no existe pecado en maldecir al diablo y los seres insensibles (plantas, rocas...). Abominar de Satanás es por definición teológica un acto de buen cristiano, situado en las antípodas de las actuaciones siniestras de los adoradores del maligno que han establecido un pacto de sangre con Lucifer. Maldiciones dirigidas a los demonios muy comunes entonces en Cataluña como «Maleit els diables coronats, y sagrats» o «Malehit sia el diable» no eran consideradas blasfemias. Otra cosa bien distinta son las expresiones orales que recaban el amparo de las huestes infernales. Según la teología tomista, los juramentos con invocación expresa al demonio tienen carácter blasfemo ya que se reclama el auxilio del diablo en situaciones críticas o anormales, rechazándose la ayuda de Dios. El blasfemador que obra de este modo se sitúa fuera del marco de valores cristianos. En principio, teólogos e inquisidores son condescendientes con los juramentos en cuyas formulas se contienen alusiones simples a las figuras diabólicas. No obstante, ciertas imprecaciones como «los diablos te lleven», «vete al diablo», o juramentarse con un «voto al diablo», -modos muy extendidos en el hablar de la población española de entonces-, eran consideradas formulas verbales de desafío destinadas a reforzar el propósito del juramento, fuente de una potencial connivencia con las fuerzas demoníacas que abriría las puertas al pacto diabólico ${ }^{66}$. Jurar «por el diablo» es un juramento de carácter blasfemo al atribuir a los entes infernales una autoridad semejante

\footnotetext{
64 Pelosse 1981, 12.

65 Delgado Ruíz 1989, 511.

66 Horeau-Dodinau 1994, 193-194.
} 
al Creador del Universo como quien jura «por Dios». Desde el punto de vista de la rigurosidad teológica no existe duda: poner por testigo al diablo o invocar su nombre es renegar de Dios en beneficio del monarca de los infiernos.

El teatro era probablemente el medio más eficiente de divulgación y «aprendizaje» que tenía la gente para conocer este lenguaje invocatorio. El diablo ocupaba un lugar importante dentro de las piezas teatrales doctas y profanas del Barroco, prolongación escenográfica en el tiempo del demonio como personaje de la tradición carnavalesca popular medieval ${ }^{67}$. El doble tratamiento asignado al diablo -cómico y serio- característica de la herencia cultural del Medioevo ${ }^{68}$ se refleja a principios del siglo XVI en las obras de Gil Vicente, Exhortaçao o la farsa de feyticeire, y Diego Sánchez de Badajóz, Farsa de la hechiceria. El diablo representado en los Autos Sacramentales religiosos y profanos del Siglo de Oro es una figura omnipresente en los diversos temas argumentales del género -temas eucarísticos, vidas de santos, episodios del Antiguo Testamento, parábolas evangélicas, sucesos históricos, episodios mitológicos-, pero, lejos de asustar al público, lo divierte muchas veces con su renquear de piernas, sus brincos torpes por el escenario y los engaños de los que es objeto. Un diablo indefenso y vulnerable a las malicias de los hombres. La situación experimentará un giro sustancial con el triunfo de la Contrarreforma católica y el control más severo de los espectáculos teatrales por parte de la autoridad religiosa y civil. El teatro dramático pierde su faceta grotesca: «El diablo carnavalesco y popular, feo y burlón, juguetón y divertido, a veces irreverente, también simpático, se perdió para el drama en el siglo XVII» ${ }^{69}$. Pedro Calderón de la Barca les da el tono lúgubre del que antes adolecían ${ }^{70}$. No obstante, el teatro profano -comedias, farsas- mantuvo parte de la antigua tradición, no así en las obras devotas.

La Iglesia ve en el teatro popular una fuente de irreverencia y de pecado que es preciso cortar. Juramentos, blasfemias e imprecaciones son intercaladas sin pudor en las farsas teatrales europeas de los siglos XV-XVI con un elevado número de expresiones denigratorias contra Cristo y la Sagrada Familia durante las representaciones $^{71}$. Las blasfemias que los diablos proferían contra Jesús y su madre en muchas de estas obras deberían escandalizar al clero, por ello no es de extrañar que para evitar problemas se tomaran precauciones como la llevada a cabo por un actor de la ciudad francesa de Aviñón que en 1470 certifica ante notario que «los anatemas e invocaciones a los demonios los decía de boca, no de corazón» ${ }^{72}$. La batalla contra este género artístico continuará siglos después en el frente laico, incorporando también en su crítica a los Autos Sacramentales ${ }^{73}$.

\footnotetext{
67 Bakntin 1974, 85-86.

68 Muchembled 2000, 31-33.

69 Ferrer Valls 1989, 322.

70 Cilveti 1997, 33-35 y 39-41.

71 Lebègne 1951, 99.

72 Lebègne 1951, 102

${ }^{73}$ En 1762, José Clavijo y Fajardo decía que los Autos Sacramentales eran piezas teatrales ofensivas para el arte y la religión, contrarias al buen gusto y a la razón, calificándolas de indecentes porque los cómicos que
} 
En el plano jurídico la Inquisición valoró de distinta manera los juramentos y blasfemias en que se imploraba el nombre y amparo de los diablos. De modo general, el Santo Oficio de Barcelona valoraba de una manera harto benigna las expresiones de alabanza a Satanás y demás servidores infernales, considerándolas parte del repertorio del vocabulario irreverente de la cultura del pueblo, sin connotaciones heréticas, merecedoras en su inmensa mayoría de una severa amonestación. Por su parte, el tribunal de Sevilla dejó de castigar con la abjuración de levi a los convictos de proferir invocaciones al demonio desde la segunda mitad del siglo XVI. A partir de esa fecha se les aplicó la simple reprensión. En el siglo XVII, los inquisidores del distrito andaluz dejaron de considerar las invocaciones a los diablos como algo herético. Juramentos blasfemos que anteriormente merecían una grave censura pasan a tener un tratamiento más condescendiente: «Válgame el diablo que Dios no tiene poder para valerme», "Valga el diablo mi alma de Dios y el alma de quien le avia criado, y por quantas mugeres ay son, puto de Dios, y reniego de Dios y que valga al diablo el alma que lo baptiço» ${ }^{74}$. Todos estos juramentos que tienen como figura central al diablo son parecidos en esencia a los escriturados en la Cataluña moderna ${ }^{75}$ :

Juramentos en los que se pone al diablo por testigo: «Los diablos men portian», «Los dimonis se m'en porten, sino es com dich», «Los dimonis se men portian lo dia de bodas, sim caso ab altre, que ab tu».

Juramentos de venganza contra el prójimo y los animales donde se menciona la figura diabólica: «Los diablos men portian sino li trenco las camas», «Los diables te tregui los ulls, y te tapia los forats ab fanch», «Los diablos se men portian, sino me la pagas», «Ja fosses al diable», «Lo diable se t'en portia», «Tants diables se t'en portian com diners m'has llevat», «Vestant al diable, reventat que foses», «No vindra un Dimoni y seten portia», «Malehit siau vois, anausen al diable».

Juramentos frente a las pesadumbres de la vida donde se alaban los demonios: «El Dimoni pot mes que Deu», «Loado sea el nombre del diablo», «El diable es digna de ser alabat», «Alabat sia el dimoni», «Tomo al diablo por señor», «Si Dios no me quiere ayudar me ayudaran los diablos».

Juramentos relacionados con la Pasión de Cristo con mención expresa del diablo: «Tras la creu esta el diable».

representaban el papel de las diversas abstracciones («La Virtud», «La Bondad», «La Belleza»), o el de los santos, o incluso el de la Virgen María, eran sujetos sin ninguna garantía moral (G. Rossi 1967, 9-96).

${ }^{74}$ Boeglin 2003, 121-144.

75 Fuentes manuscritas consultadas: S. Feliu de Guixols, Sermó de las impaciencias y las malas paraulas, APCC, Siglo XVIII, Pliego suelto; Sermó de missió, BUB, Ms. 693; Sermón misional, BUB, Ms. 694; Fuentes impresas consultadas: Confessional, Barcelona, 1535; A. Baucells, Font mystica y sagrada del paradis, Barcelona, 1704; A. Marsal, Catecismo explicado y predicado, Barcelona, 1717; J. Plens, Catechisme pastoral de pláticas doctrinals, y espirituals, per tots los diumenges del any, Barcelona, 1699; F. Romeu, Cura pastoral de almas en diez sermones, Siglo XVIII; P. Salses, Promptuari moral sagrat, y cathecisme pastoral de pláticas doctrinals y espirituals sobre tots los puntos de la doctrina christiana per predicar en la Quaresma, Diumenges, y demes festivitats, Rogativas per aygua, y altres necessitats, Barcelona, 1754. 


\subsection{LAS APORTACIONES CULTURALES EXTERIORES: JUDAÍSMO E ISLAM}

Francisco Márquez Villanueva localiza una fuente probable de ateísmo en las aljamas judías ${ }^{76}$ y musulmanas de la península ibérica desde los últimos siglos de la Edad Media ${ }^{77}$. Un materialismo que bebe de fuentes averroístas basado en el discurso de la negación de la resurrección y la inmortalidad del alma humana, el libre albedrío y la Providencia celestial. Tesis filosófica que tendrá una notable repercusión en el pensamiento intelectual europeo de la Baja Edad Media ${ }^{78}$. Averroes intenta conciliar la revelación musulmana y la lógica aristotélica en un intento por superar los aspectos arcaicos e irracionales de la religión, un propósito de resolver la contradicción entre la fe y la filosofía ${ }^{79}$. El averroísmo rechaza la idea de un Dios creador y causa primera de todo cuanto existe, niega el dogma de la revelación, la Trinidad, la eficacia de las oraciones, las limosnas, las letanías y todo comienzo de las cosas sagradas, una teoría filosófica que se extenderá de las aljamas a muchos conversos, judaizantes o no, propagada principalmente a través de la obra de Maimónides (1135-1204), el más célebre rabino y teólogo judío de la Edad Media ${ }^{80}$. Una corriente de escepticismo religioso que florecerá especialmente en las fronteras de los mundos musulmán y cristiano ${ }^{81}$. Según Joseph Pérez, los primeros brotes de este racionalismo filosófico que impregnará a la cultura hebraica española se encuentran en las comunidades judías de Montpellier, Perpiñán y Narbona ${ }^{82}$, una opinión no compartida por Márquez Villanueva ${ }^{83}$.

\footnotetext{
${ }^{76}$ En Cataluña se utilizó la palabra «qhahal» que derivó en «call», comunidad o congregación de los judíos, aunque posteriormente pasó a designar el recinto urbano habitado por los judíos, asimilación terminológica de «judería» (Millas Vallicrosa, F. Vendrell Gallestra 1967, 9-17).

77 Márquez Villanueva 1994, 9-17.

78 Granada Martínez 1998, 163-182.

${ }^{79}$ La Iglesia consideró como herejía las enseñanzas de la filosofía averroista. En el siglo XIII sus tesis fueron condenadas formalmente hasta en nueve ocasiones, la última en 1277, pero sobrevivieron con fuerza hasta el siglo XVI en filósofos del humanismo renacentista como Giordano Bruno, Pico Della Mirandola y Cesare Cremonini.

${ }^{80}$ La traducción de la obra principal de Maimónides, la Guía de perplejo (1190), del árabe al hebreo tuvo amplias repercusiones. Provocó el nacimiento de una corriente averroísta judía y abrió las puertas a un conocimiento intelectual del judaísmo. El nuevo método filosófico-racionalista penetró en ámbitos como la gramática, la filología, la teología o el derecho. Los judíos ortodoxos partidarios de la vieja tradicion se levantaron contra las ideas del filósofo cordobés y pasó a ser considerado un hereje y apóstata (Chahlane 2005, 111-123).

81 Minois 1998, 74.

82 Pérez 2003, 75.

${ }^{83}$ Márquez Villanueva defiende la existencia de una tradición averroísta hispana diferente del resto de los países europeos. Según sus consideraciones, en Francia y en Italia triunfó el llamado averroísmo latino. En España, bien al contrario, prevaleció un averroísmo «popular» o «semítico» basado únicamente en fuentes judías o árabes. Esta tradición cultural sobrevive en los siglos XVI y XVII incitando el interés cultural de los diferentes grupos de novatores españoles (Márquez Villanueva 1987, 121-132). Jesús Villanueva cuestiona esta tesis. Piensa que esta supuesta continuidad histórica no esta suficientemente demostrada. Argumenta que si bien la cultura medieval de inspiración árabe-judía está todavía presente en la España de principios del siglo XVI, no lo es menos que ésta se encontraba en claro retroceso ante el avance imparable de la cultura humanista procedente de Italia. El historiador catalán sostiene que el averroísmo de los siglos XVI y XVII fue más bien un ejercicio de reapropiación de una herencia cultural olvidada, ahora circulando en contextos absolutamente nuevos, factor que no comporta, a su juicio, ningún fenómeno de continuidad ideológica (J. Villanueva, art. cit.).
} 
La penetración de la filosofía de Averroes tendrá efectos devastadores sobre la cohesión y solidaridad interna de las aljamas judías españolas, sembrando de disensiones los cimientos espirituales de la fe mosaica ${ }^{84}$. Las ideas averroístas encontraron buena recepción especialmente entre las élites judías de la Corte y las profesiones liberales $^{85}$. El impacto averroísta tiene consecuencias graves en la desestructuración del pensamiento religioso tradicional de los judíos españoles

Desde fines del siglo XIV así como a lo largo de la primera mitad del siglo XV, las aljamas se vieron sacudidas por una oleada de escepticismo religioso, y que se plasmaba en la adopción de posturas averroístas. Este hecho será, en opinión de Y. Baer, determinante a la hora de las conversiones masivas que tienen lugar a partir de 1391, haciendo patente la manera en que se había ido minando el sentimiento religioso de ciertos miembros de las comunidades judías, de cómo había ido cundiendo entre algunos hebreos -sobre todo entre los más poderosos y encumbradosun pesimismo religioso, que les hacía apartarse de la religión de sus mayores, sin que esto implicara, a pesar de la frecuencia con que se producían las conversiones de estos individuos, un acercamiento al cristianismo ${ }^{86}$.

En la primera mitad del siglo XV las autoridades rabínicas pietistas de las aljamas judías de Castilla, partidarias de mantenerse firmes en las tradiciones y costumbres de sus antepasados, claman contra el averroísmo filosófico de los judíos cortesanos que viven de espaldas a la religión ortodoxa mosaica. Son defensores de la interpretación literal de los textos sagrados, fuente de inspiración de la corriente mística de la cabala.

Desde el siglo XIII la cuestión de las blasfemias judías, fuesen de inspiración rabínica ortodoxa o averroísta, era motivo de importante preocupación para la autoridad real y la jerarquía eclesiástica de Cataluña. La situación no había cambiado sustancialmente a pesar de las radicales medidas tomadas por el monarca Jaime I para atajar el problema durante los años de su reinado ${ }^{87}$.

En Cataluña el Santo Oficio pronto se encargó de cortar cualquier disidencia a la doctrina oficial. El 29 de mayo de 1264, el rey Jaime I absolvió a Astruc de Porta, judío de Vilafranca del Penedés (Barcelona), de las penas que le habían sido impuestas por los inquisidores al encontrarlo culpable de proferir palabras blasfemas In vituperium Jhesus XI durante ciertas discusiones mantenidas con cristianos ${ }^{88}$. La misma

\footnotetext{
84 García Casar 2002, 429.

85 Renan y Pacheco Pinglet 1992.

${ }^{86}$ Rábade Obradó 1990, 309.

${ }^{87}$ El 27 de marzo de 1264 el soberano ordenó a todos los judíos que estuvieran bajo su jurisdicción a borrar en un plazo de tres meses todas las blasfemias referentes a Jesucristo y a la Virgen que ellos mismos pudieran localizar en sus textos sagrados, informando de ello a los frailes predicadores. Transcurrido este tiempo los libros serían quemados públicamente salvo que los propietarios demostraran ante los jueces nombrados por el monarca que los pasajes literarios no constituían blasfemia (Casanovas Miró 2005, 120-121).

88 Casanovas Miró 2005, 117.
} 
absolución recibió el 12 de abril de 1265 Bonastruch de Porta, judío natural de Gerona, maestro de hebreo en aquella ciudad, fiel seguidor de la tradición ortodoxa más pura, acusado por los inquisidores de insultar e injuriar a Jesús y a su Madre durante una discusión sobre un libro que a juicio del Santo Oficio contenía blasfemias ${ }^{89}$. En 1266 fueron juzgados el batlle (alcalde), Yehuda de la Caballería y su yerno Astrug Bonsenyor, junto con otros familiares, acusados de haberse burlado de un crucifijo, aunque finalmente fueron absueltos por el rey ${ }^{90}$. Durante los mismos años, la Inquisición medieval en Cataluña actuó contra unos judíos por blasfemar y escarnecer la Eucaristía ${ }^{91}$. Esta política represora se acentuará en la siguiente centuria.

Depositado en las colecciones manuscritas de la Biblioteca Nacional de París hay un memorial del inquisidor de Aragón donde se consignan diversas denuncias de fines del siglo XIV correspondientes a las diócesis catalanas de Gerona, Urgel, Lérida y $\mathrm{Vic}^{92}$. El texto original debería contar con más de ciento sesenta páginas de las que se conservan solamente veinte y alrededor de cien delaciones escrituradas en el texto primitivo reducidas ahora a unas pocas acusaciones. Las denuncias están clasificadas por episcopados y cuyo primer título reza así cuando se refiere a la mitra gerundense: «Delaciones contra aliquos qui sunt de episcopatu Gerundensi». La misma fórmula se reproduce para las siguientes diócesis. Se cita el nombre de la persona denunciada, oficio y domicilio. Se sigue el mismo protocolo para el denunciante cuando todavía las delaciones no eran anónimas. A continuación se escriben los nombres de los testigos. Las acusaciones más frecuentes son por brujería y superstición (estar en posesión de libros de magia para invocar a los demonios). En segundo lugar hay una serie de interesantes denuncias contra judíos blasfemos. Yssachum Vitalem Revage de Gerona es acusado de tratar públicamente a la Virgen de mujer ordinaria y puta al decir: «¿Com podets fer vos altres tantes noves d'aytal fembra, quis livram a hom axi com a puta? $\rangle^{93}$. Otros judíos son denunciados por manifestar opiniones heterodoxas. Un judío de la localidad costera de Pals en el norte de Gerona apellidado Saumman es declarado blasfemo por negar las potencias divinas de Cristo y la virginidad de María. Vitalem Yssac corrió la misma suerte al decir que no existía el infierno y que los demonios nacían y morían ${ }^{94}$. También era habitual entre los judíos manifestar la idea de que no es pecado comer carne durante la Cuaresma y negar el dogma de la Transustanciación y el sacramento de la Eucaristía, al rechazar la creencia de que el cuerpo y la sangre de Cristo están verdaderamente en la hostia consagrada por el sacerdote en el oficio de la misa. Completan el legajo algunas denuncias a religiosos incriminados por herejía y predicaciones falsas ${ }^{95}$.

\footnotetext{
89 Casanovas Miró 2005, 118.

90 Blázquez Miguel 1990, 26.

${ }^{91}$ Hernando 2005, 9

92 Omont 1905, 261-268.

93 Omont 1905, 264.

94 Omont 1905, 265.

95 Omont 1905, 267-268.
} 
La comunidad morisca de la península también rechazaba ciertos artículos del culto y dogma de fe cristiano. Algunos moriscos rechazaban cualquier veneración a la cruz de Cristo. En Aragón y Valencia se sucedían los ultrajes sacrílegos a los crucifijos por parte de este segmento étnico de la población peninsular (propinarles azotes, arrojarlos al suelo con fuerza, pisotearlos hasta que se quebraran, levantarse las faldas las mujeres y orinar encima de ellos) ${ }^{96}$. Ciertos moriscos no mostraban ningún pudor en manifestar opiniones anticlericales y su abierto rechazo a los dogmas y sacramentos de la Iglesia ${ }^{97}$. Por si esto no fuera suficiente las aljamas musulmanas de Andalucía expresaban dudas acerca de la virginidad de la Madre de Cristo ${ }^{98}$, y que fuera la suerte y no Dios quien guiará los destinos de la vida humana ${ }^{99}$. Un síntoma claro del peligro que podía entrañar la penetración de semejantes creencias heterodoxas en el espíritu religioso del pueblo lo tenemos en la actitud de ensañamiento emprendida por la Inquisición española contra los blasfemos moriscos frente a la relativa relajación mostrada ante los cristianos viejos procesados por el mismo delito. Los moriscos juzgados por actos de impiedad o blasfemias serán tratados muy a menudo como herejes, en lugar de considerárseles individuos cortos de entendederas víctimas de la irreflexión u ofuscación mental como sucedía entre la gran mayoría de casos en los que estaba encartada la población cristiana vieja ${ }^{100}$. Algunos ejemplos extraídos de los registros de procesos incoados por el Santo Oficio de Murcia son muy ilustrativos. María de Morata, morisca granadina, vecina de Albacete, se la puso en el potro de tormento en 1594 inculpada de deshonrar el honor de María Santísima, un hecho excepcional en el procedimiento jurídico seguido habitualmente contra los blasfemos, ya que los cristianos viejos nunca se les aplicó la tortura para que confesaran si era verdad la acusación de haber renegado públicamente de la virginidad de María. Declarada culpable fue condenada a tres años de prisión ${ }^{101}$. En 1579 estuvo a punto de sufrir idéntica suerte otro morisco vecino de Chinchilla, reconoció la inculpación y fue absuelto ${ }^{102}$. En 1657, Luis Borrico Gato, morisco de Almansa, afirmaba que «Dios no había hecho bien las cosas, porque unos eran moros, otros cristianos y otros judíos, cuando todos debían ser uno», expresión que le condujo a ser recluido durante un cierto tiempo y a que se le diesen doscientos azotes ${ }^{103}$.

¿Tuvo una influencia importante este pensamiento protomaterialista entre los cristianos viejos de la Cataluña medieval? Kamen cree que no debe subestimarse el peso del influjo cultural árabe en las ideas religiosas de la gente ordinaria:

\footnotetext{
96 Monter 1992, 270.

97 Amelang 2012, 61-62.

98 En los procesos inquisitoriales de los tribunales andaluces se encuentran testimonios de conversos críticos con la devoción mariana, mientras que en la literatura del Siglo de Oro se ofrecen ejemplos en uno y en otro sentido. (García Pedraz 2002, 663).

${ }^{99}$ Boeglin 2006, 230.

100 García Arenal 1978, 40.

101 Blázquez Miguel 1985, 54-55.

102 Blázquez Miguel 1985, 55.

103 Blázquez Miguel 1985, 55.
} 
El escepticismo respecto al más allá parece haber sido algo corriente, no hay infierno ni purgatorio, no hay resurrección de los muertos, los moros como los cristianos se podían salvar, los moros no iban al infierno. Estos puntos de vista formaban parte de una herencia común del razonamiento popular, en un país mediterráneo en el que había frecuentes contactos con musulmanes y una comprensión nada pequeña de su cultura ${ }^{104}$.

El Santo Oficio surgido en 1478 de la reorganización de la antigua institución medieval dirigirá su represión contra los blasfemos cristianos de nueva hornada procedentes de la vieja religión hebrea y musulmana. En la Inquisición de Toledo son abundantes las causas por blasfemia entre los judíos conversos. Algunas tenían un marcado componente judaico o talmúdico en sus ataques a la Virgen y a las imágenes de Cristo $^{105}$, acusados de descreimiento religioso por sostener la opinión de que el hombre fue creado sólo para nacer y morir, como las plantas y los animales, sin ninguna proyección espiritualista ${ }^{106}$.

En Cataluña los conversos no representaron amenaza alguna para la ortodoxia. La presencia de judíos, incluso en 1492, era exigua ${ }^{107}$. Esta es la razón principal de que el tribunal inquisitorial de Barcelona no procesara a ningún converso por delito de blasfemia $^{108}$. La Inquisición de Cataluña tampoco tuvo problemas con los moriscos por su escaso número ${ }^{109}$. La hostilidad estaba, teóricamente, del lado de las nuevas poblaciones conversas, pero deducir de aquí la conjetura de un hipotético contagio de ideas anticrísticas judías y musulmanas sobre el conjunto de la sociedad cristiana vieja en una prolongación de continuidad desde los tiempos medievales resulta muy arriesgado de establecer. Un judeoconverso que insulta a la Virgen, ¿es incrédulo, o simplemente es una persona que no cree en el cristianismo, pero si en el judaísmo?, y por tanto, no es ateo ni incrédulo. Los moriscos que rechazan dogmas cristianos, ¿eran incrédulos o simplemente musulmanes mal convertidos?

\section{JURAMENTOS BLASFEMOS CONTRA DIOS Y LA VIRGEN}

La inmensa mayoría de juramentos, blasfemias, maldiciones e injurias contra Dios y su Hijo se expresan en situaciones de cólera irascible y desaliento sin nin-

\footnotetext{
104 Kamen 1998, 83.

105 Caro Baroja 2000, 381-389.

106 Pérez 2003, 76.

107 Kamen 1998, 255.

108 Sin embargo, durante los primeros decenios del siglo XVI la represión inquisitorial fue especialmente sangrienta respecto a las condenas de muerte. Esta contradicción posee una explicación: la casi totalidad de los reos a la pena capital eran relapsos, personas que ya habían sido procesadas y condenadas levemente con anterioridad, pero como persistían en la práctica de la religión judaica fueron juzgados de nuevo, declarados judaizantes y enviados a la hoguera. (Blázquez Miguel 1990, 43).

109 Sus asentamientos se concentraban en la zona del Ebro con la ciudad de Tortosa como centro demográfico más importante.
} 
gún tipo de menciones a la religión mosaica o musulmana. Sorprende especialmente la ausencia de noticias de judíos en la memoria blasfema de la gente, silencio oral difícil de explicar pues es de suponer que la cultura popular mantendría aún cierto recuerdo generacional de las sangrientas persecuciones de este colectivo religioso en tierras catalanas durante los siglos XIII-XV. Destaca la ausencia de sentimientos de aversión a los judíos en el lenguaje blasfemo de los cristianos viejos en relación a la figura del Creador. No se han encontrado blasfemias de tipo racial como «Dios es judío» o «Dios es moro». Probablemente este género de injurias serían entonces puro arcaísmo al no corresponderse con realidades sociales comprensibles para las personas. Tampoco se han hallado insultos en los que se atribuyan a Jesucristo signos identitarios de infidelidad conyugal como decir «Por los cuernos de Cristo», muy presentes en otras partes de la península como en el caso de Andalucía ${ }^{110}$, de otro lado, un insulto muy común entre la población urbana y rural de Cataluña desde la Edad Media ${ }^{111}$. El abanico de votos e imprecaciones que recibían las potencias celestiales por parte de la gente ordinaria era ciertamente heterogéneo ${ }^{112}$ :

Juramentos en los que se pone a Dios por testigo: «Per Deu es aixi», «Poso a Deu per testimoni que no tinc això», «Així com Deu està al cel es veritat, reventat sia», «A fe de Crist», «Això es veritat lo que dich, com Deu està en lo cel, com Deu es fill de María», «Juro a Deu que ahir me trobava a tal casa», «A fe de Deu, avuy es diumenge», «Juro a Deu de donar dos doblos al hospital», «Com Deu es fill de María», «Com Deu es Deu», «Com Deu es Deu no he anat a tal part», «Be ho sab Deu», «Devant de Deu es així», «Deu ho veu», «Voto a Christo», «Això es tant verdader o veritat com Deu», «Com Deu està en lo cel no he vist a fulano», «Per aquell Cel de Deu es veritat», «Que no vegi la cara de Deu si no es veritat», «Com Deu està en lo cel per lo Nadal per la collita, per lo vendra el vi seràn diners», «Es tant cert lo que yo dich, com Deu està en lo cel», «Per vida de Christo», «Voto a Deu sagrat», «Voto a Christo coronat», «Per Deu sagrat y coronat», «Per vida de Deu sagrat», «Per vida de Deu», «Com Deu es Deu», «Juro a Deu que farè tal cosa», «Per Deu es així», «Poso a Deu per testimoni, que no tinc això».

Juramentos y maldiciones despreciativas y desafiadoras a Dios: «Renego de Deu, y de la fe», «Encara que pesia a Deu, vulga o no vulga Deu», «A pesar de Deu, tinch de fer asso», «Farè això, vulla o no vulla Deu», «A despit de Deu», «Malehit sia Deu», «Maleyt l'ayre de Deu», «Malehit lo foch de Deu», «Malehida la terra de Deu», « Ni Christo pot fer que guanyi», «Deu apar que dormi», «Renego de Deu,

\footnotetext{
110 Boeglin 2006, 225.

111 En la Barcelona de finales de la Edad Media los hombres sometidos a la vergüenza de ver reconocida socialmente la infidelidad sexual de sus mujeres recibían el calificativo injurioso de «cornuts». Uno de los insultos que más molestaban a los barceloneses de entonces era escuchar: «No van tots los cornuts per la muntanya ans van per los plans" («No van todos los cornudos por la montaña, antes bien van por el llano»), (Vinyoles 1990, 160).

${ }^{112}$ Las fuentes consultadas son las referenciadas en la nota setenta y tres.
} 
y de sa mare», «Renego del Christo que porto en la front», «Mala ira de Deu», «Maleheixo a Deu, a María Santísima, als Sants», «Mala ira de Deu», «Mal llamp de Deu», «Juro a Deu que tinch de dir, que tal sant fou un hipòcrita», «Lo foch de Deu», «La terra de Deu».

Juramentos de venganza contra el prójimo y los animales implicando la figura de Dios: «Deu no es just, sino envia la mort a fulano», «Per aquell cel de Deu, que me l'ha de pagar», «Com Deu està al cel, que li romperè las costellas», «Per aquell cel de Deu, que me las pagaràs», «A fe de Deu, hi havem de anar a robar las gallinas, nos las portarem totas com Deu està al cel», «Com Deu està en el cel quet tinch que trenca las camas», «Mala mort te doni Deu», «Per la vida de Christo, que te he de matar», "Com hi ha Deu, no te he de perdonar», «La cara de Deu no vegias», «Per fe de Deu quel tinc que afeitar a garrotadas, quel tinch de matar», «Mal regne de Deu que se tan portia», «A fe de Deu, que tinc de dir, que fulano es un lladre», «Per aquesta cara de Deu, que no me la portaràs al molí», «Ja rebentasses de pur amor de Deu», «Deu no vulgui sino te esclafi», «A fe de Deu no passarà aquesta semana, que no estiga satisfet», «Dios no será Dios, ni la Virgen será Virgen, si te perdona ese pecado», «Ira de Deu te matia», «Ira de Deu te toch», «Ira de Deu te sech», «Malaheixo los animals de Deu».

Juramentos frente a las pesadumbres de la vida con expresiónes de descontento y amenazas a Dios: «Deu no te providencia, misericordia, justicia», «Deu es injust, no hi ha poder en Deu per ajudarme», «Deu no es omnipotent, no es sant, no es just, y misericordiòs», «No es posible que Deu sia piadòs, pues me envia tants treballs», «Que sia tant desgraciat, que ni Deu lo pot fer guanyar», «Deu no te cuidado dels pobres, no reparteix be las cosas, no te providencia sino per los richs, als uns dona sobrat, y als altres deixa mort de fam», «Quin mal he fet, perque Deu me tracti de aquesta manera», «Ara ja veus, que Deu nos recorda de mi, ses olvidat de mes cosas», «Ja coneix que te altra cosa a fer, que pensar amb mi, ni Deu, ni Sant Pere me podran ajudar», «Non pot tractar mes malament Deu quel quem tracta», «Deu no fa justicia, me castiga mes, fa accipiò de personas, ja sos compares, y comares, a uns dona tot, y a mi me lleva tot, sens dexarme res», «Deu als traidors ajuda, als lladres patrocina, als quens escorxan dona tot lo quen ha menester», «Ni Deu sab lo ques fa, que si jo me haguès trobat al principi del mon, mes cosas hauria fet millor que ell», «Deu es injust, ques cruel, ques tirà, ques aceptador de personas», «Mala mort me doni Deu», «Deu no es lo que es, sino fa plourer estos dias que tenim tanta axut», «Deu no goberna be'l mon», «Deu es cinich, es cruel», «Reniego del Dios que me crió, y me sustenta en la tierra».

Juramentos relacionados con los objetos de la Pasión de Cristo: «Renego de la creu de Christo», «Per aquesta creu de Deu, que adoro, ho vaig sentir a dir», «A fe de Deu, per aquesta creu no passarà aquest mes, que estiga satisfet», «Per aquesta creu queu dirè a ton pare, quet darè cuatre patacadas ben donadas», «Per esta creu te he de perseguir fins a la mort», «Reniego de Christo crucificado»- 
La madre de Cristo era otra figura favorita en las blasfemias («María Santíssima era una doneta», «María Santíssima era una gitana», «La Virgen es una bujarrona») y juramentos de los cristianos («Per vida de Maria Santíssima», «Com María Santíssima es verge», «Es tant cert com María Santíssima es Verge, que no he tocat tal cosa»). La Virgen estaba siempre presente en la vida diaria de los católicos, como asistente y partícipe de las vivencias cotidianas de las personas, en los buenos momentos y en las circunstancias desfavorables («Es veritat que no passaré mes el Rosari, si la mare de Deu no fa parar els trons»). Su figura representa la principal vía de desahogo emocional de los individuos en los instantes difíciles frente a los santos que parecen estar más distanciados en la ruda rutina diaria de la gente común. ¿Cómo entender entonces las blasfemias a la Virgen en una sociedad que hace ostentación de una profunda adoración mariana? ¿Simple formalismo verbal de rebeldía ante las injusticias en situaciones de menor autocontrol personal o expresiones de una religiosidad crítica que busca el enfrentamiento en relación a lo sagrado?

Las blasfemias marianas aparecen durante las últimas centurias de la Edad Media europea en un proceso sincrónico al crecimiento popular del culto a María ${ }^{113}$. Los insultos blasfemos dirigidos a la pureza sexual de la Virgen son graves pues atentan al dogma católico de la virginidad mariana. Este es uno de los artículos de fe más difíciles de asimilar para la gente rural, un hecho del todo inexplicable para una población acostumbrada al ciclo natural biológico de la vida y de la muerte. En los procesos criminales de la vegueria ${ }^{114}$ de Lérida correspondientes al siglo $\mathrm{XV}$, los jueces civiles transcriben mucho mejor el lenguaje crudo del pueblo que los tribunales religiosos del Principado, calificándose a menudo a la Virgen como «puta/bagassa o vagassa» (prostituta): «malgrat nagués la puta de Santa María», «malgrat nagués la vagaza de la Verge Maria» ${ }^{115}$. Como en el caso de los juramentos crísticos, la figura de la madre del Redentor sufre un proceso de degradación moral que desacredita por completo su autoridad divina, atribuyéndole las cualidades femeninas del oficio más viejo del mundo: la prostitución. El juramento vulnera la doctrina de fe católica de la pureza y castidad de la Virgen. Una vez más nos enfrentamos a una cuestión con todos los tintes de irresoluble. ¿Las blasfemias marianas son únicamente achacables al razonamiento de la lógica popular? ¿Tienen alguna relación con la herencia cultural de otras confesiones religiosas?

La controversia sobre la virginidad de María era un tema antiguo que había atravesado toda la Edad Media con polémicas doctrinales entre teólogos cristianos y rabinos. La religión hebraica no admitía el nacimiento sobrenatural de Jesús, por consiguiente los judíos no aceptaban la castidad virginal de María, dicho en otras palabras, negando la pureza sexual de la Virgen no reconocían la llegada del Mesías y degradaban a la Madre de Jesús a la categoría de mujer mundana con todas las

\footnotetext{
113 Llompart 1973, 139.

114 Una de las diecisiete divisiones administrativas en las que estaba dividido el territorio de Cataluña antes de 1715 .

115 Gómez 1992, 380.
} 
apetencias carnales propias de una persona de su sexo. Con relación a la tradición religiosa musulmana, el Corán cree en el alumbramiento virginal de María. En el texto más importante de la religión islámica el nombre de la Madre de Cristo aparece treinta y cuatro veces, explicándose cinco episodios de su vida, entre ellos, su natividad, anunciación y parto. El profeta Mahoma respetaba profundamente a María, considerándola una predilecta de Dios y un ejemplo para los creyentes. La Virgen no representaba, pues, una figura de infamia para los musulmanes ${ }^{116}$.

Los mismos interrogantes se plantean en relación a las blasfemias a los santos. En el judaísmo el concepto de santidad es complejo, distinto del mundo católico. El Islam y el cristianismo protestante rechazan el culto a los santos y de sus reliquias ${ }^{117}$. Estas confesiones son hostiles a la veneración cristiana de los cuerpos sagrados canonizados por la Iglesia, y niegan que estos posean algún poder de intercesión como mediadores entre los hombres y el Creador. Los juramentos y maldiciones dirigidas a los abogados celestes de los cristianos no son demasiado frecuentes. Por lo general, los insultos suelen tener como destinatarios al conjunto de los auxiliares de Dios en el cielo: «Malehit sia lo sant que te ajuda», «Mal ayan todos los santos y vos también». Hay pocas menciones particulares. Habitualmente se injuria a los santos que se conocen bien, con San Pedro a la cabeza: «Per vida de Sant Pere», «Voto a Sant Pere», «Renego de Sant Pere», «A pesar de Sant Pere tinch de fer tal cosa», «Voto a Sant Quintí»».

\section{JURAMENTOS BLASFEMOS CONTRA LOS SACRAMENTOS Y LA ES- PIRITUALIDAD CRISTIANA}

Las blasfemias eucarísticas están documentadas desde el siglo XIII, coincidiendo con el inicio de una política pedagógica de explicación doctrinal de las virtudes del sacramento eucarístico entre la población. La Iglesia se percata de la manifiesta ignorancia de muchos cristianos sobre la naturaleza sacramental de la Eucaristía ${ }^{118}$. Las declaraciones de numerosos inculpados por la Inquisición española reflejan la idea arraigada entre la gente común de la imposibilidad de que el cuerpo y la sangre de Cristo pudieran estar contenidos en un trozo de pan. El desconocimiento de la gente ordinaria acerca de la doctrina de la transustanciación eucarística parecer ser cierto en el caso de la Cataluña del siglo XVI ${ }^{119}$. En 1589, el misionero apostólico agustino Antonio de Acevedo, tras más de veinte años de ejercicio pastoral en Cataluña, se lamentaba del estado de profunda ignorancia espiritual en que se hallaban inmersos muchos habitantes del Principado:

\footnotetext{
${ }^{116}$ No obstante, Rogério de Oliveira Ribas en su estudio sobre la tipología delictiva en las fuentes de la Inquisición portuguesa durante el siglo XVI localiza casos aislados de moriscos que niegan la virginidad de María (Oliveira Ribas, 2004).

117 No obstante, una de las principales corrientes de la religión islámica, el chiismo, reconoce a santos cuyas tumbas son destino de peregrinación.

118 Llompart 1973, 148.

119 Kamen 1998, 84.
} 
Si preguntays a un rústico que adora en el sacramento dirá mil desatinos, yo conozco uno, que yéndose a ordenar de missa, preguntado de quien estaba en la hostia, respondió, que baxaba del cielo un Ángel, y que estaba allí. Y muchos ya que digan que está allí Dios, y hombre, no entienden cosa dello, y de la misma manera adora al Sacramento que a un crucifijo ${ }^{120}$.

En el noroeste peninsular se repetía la misma situación. En 1585, los inquisidores del Santo Oficio de Galicia admitieron que estaba muy extendida la duda de la presencia de Cristo en el sacramento de la Eucaristía, pero que esto ocurría «más por ignorancia que por malicia» ${ }^{121}$. El escaso número de referencias sobre el dogma sacramental eucarístico y las potencias espirituales de Jesucristo y la Virgen María en los juramentos y blasfemias del vocabulario de la gente común indicaría un importante desconocimiento y falta de interés popular en esta materia fundamental del catecismo cristiano. En su estudio sobre la Inquisición de Logroño, María de los Ángeles Cristóbal Martín destaca la ausencia casi total de expresiones blasfematorias y de juramentos de esta categoría en los procesos inquisitoriales ${ }^{122}$. Esta historiadora lo atribuye a la ignorancia del dogma del sacrificio eucarístico entre la inmensa mayoría de la población castellana de los siglos XVI y XVII, y a una cierta desorientación jurídica por parte de los inquisidores ${ }^{123}$. Este género de blasfemias no son demasiado abundantes en los registros documentales de la Cataluña del Antiguo Régimen si lo comparamos con la gran cantidad de insultos dirigidos a Dios Padre y a su Hijo consignados en las fuentes, en la línea de lo que sucedía en Castilla:

Juramentos y maldiciones relacionados con la espiritualidad y los sacramentos: «A fe de christià», «A fe de home cristià», «Com ha ha Deu, es tant veritat com lo Evangeli se a dit avuy», «Per la hostia, que han alsat avuy», «Com es veritat lo Evangeli», «Per la mia anima», «Com soc cristià», «Com soc batejar», «Es tanta veritat lo que diu aquest home, com el Evangeli que se ha cantat avuy», «Per la salvació de la meva anima me la pagaràs», «Per la hostia consagrada y por el Santísimo Sacramento era cierto que no lo había hecho», «Reniego de Cristo crucificado y de quantas potencias tiene, y de la hostia consagrada y cáliz consagrado, y de quantos santos haya en el cielo», «Renego de la chrisma que tinch», «La Passió y los sagraments se condemnen», «Reniego de la Santíssima Trinidad», «Renego del chrisma que porto en lo front», «Renego de la fe católica».

120 A. de Acevedo, Catecismo de los misterios de la Fe, con la exposición del Símbolo de los Santos Apóstoles, donde se enseña, todo lo que un fiel christiano está obligado a creer, y un cura de almas a saber, para enseñar a sus ovejas, Barcelona, 1589,104.

121 Kamen 1998, 165.

122 Cristóbal Martín 1986, 86.

123 Entre los inquisidores españoles parece reinar una cierta confusión respecto a la calificación teológica que debía otorgarse a esta clase de juramentos blasfemos. Jean-Pierre Dedieu dice que en 1562 la Inquisición de Toledo condenó a Inés de la Parra por decir: «Reniego del Santo Crisma». Ante la incertidumbre de algunos inquisidores se recurrió al dictamen del Consejo de la Suprema. Señala el historiador francés que en tiempos del inquisidor Salazar (1614-1635) la Inquisición no juzgaba esa blasfemia (Dedieu 1981, 216). 
En este tipo de fraseología blasfematoria se entremezclan, como en las anteriores categorías descritas, los juramentos simples de venganza contra el prójimo en los que se pone por testigo una facultad espiritual, como los reniegos blasfemos de abierto desafío a los sacramentos y la espiritualidad cristiana en situaciones de descontento personal.

\section{CONCLUSIONES}

Al término de esta exposición resulta ciertamente difícil establecer conclusiones definitivas ante los interrogantes y dudas surgidas en el transcurso del desarrollo explicativo del estudio. El resultado final reúne una serie de afirmaciones verificables documentalmente con bastantes incertidumbres sobre el lugar que ocupaba el lenguaje blasfemo en su relación con el pensamiento ateísta en la vida religiosa y cultural de los catalanes de antaño.

La blasfemia se inscribe en el marco de las conductas sociales de una gran parte de la cultura española de la Edad Media y Moderna en una catolicidad que privilegia mucho más las formas exteriores de piedad religiosa del ceremonial litúrgico en menoscabo de las normas morales prescritas por la Iglesia. En los municipios catalanes las blasfemias forman parte del lenguaje corriente de muchas personas y en lugares de intensa sociabilidad vecinal como tabernas o mesas de juego es el habla dominante para desesperación de los clérigos reformadores. La gente blasfema cuando se tercia la mínima ocasión, a menudo durante los accesos de cólera relacionados con los juegos de naipes o dados, en las celebraciones festivas acompañadas frecuentemente de un consumo desmesurado de alcohol que libera los sentimientos humanos más primarios, o como procedimiento para mitigar las aflicciones personales ante las penalidades cotidianas que impone la dura vida diaria. En cada parroquia hay inconformistas religiosos que no cumplen con el deber de confesar y comulgar por Pascua o manifiestan su malestar interno mediante blasfemias, sin que ello presuponga ninguna clase de disidencia religiosa o ateísmo. Ciertos oficios (soldados, arrieros...) descollaban especialmente por su brutalidad al hablar.

Con las informaciones disponibles es difícil aseverar si la herencia cultural judía y árabe desempeñó algún tipo de influencia cultural relevante en el proceso de construcción del pensamiento blasfemo popular en la Cataluña de los siglos XVI-XVIII que condujese a la elaboración de un pensamiento ateísta primario en ciertas personas; frente al peso determinante de la tradición cultural cristiana en la construcción del vocabulario blasfemo significado en la figura diabólica. En la fraseología blasfema de los cristianos viejos se invoca al diablo, se reniega de Dios y de los sacramentos de la Iglesia, se expresan dudas sobre la virginidad de la Madre de Cristo y la eficacia de las virtudes teologales cristianas. El léxico blasfemo significado en ciertas expresiones orales ateístas, respondería, probablemente, más al sentido común de la cultura popular y a los arrebatos de cólera incontrolables de la gente que a razonamientos con base intelectual cristiana o herederos de otras confesiones religiosas. 


\section{FUENTES DOCUMENTALES}

\section{ABREVIATURAS. SIGLAS DE ARCHIVOS}

ADB: Archivo Diocesano de Barcelona.

AHN. INQ: Archivo Histórico Nacional. Inquisición.

APCC: Archivo de los Padres Capuchinos de Cataluña.

APFC: Archivo de los Padres Franciscanos de Cataluña.

BUB: Biblioteca Universitaria de Barcelona.

\section{FUENTES MANUSCRITAS}

\section{ADB}

Registra Gratiarum, 1656-1662, Vol. 65.

AHN. INQ

Relaciones de causas de fe, Libros 730, 731, 732, 733, 734, 735, Siglos XVI-XVII.

Legajo, 2170, Siglo XVIII.

APCC

S. Feliu de Guixols, Sermó de las impaciencias y las malas paraulas, Ms. sin numerar, Siglo XVIII.

APFC

Libro verde de la fundación del Colegio Seminario de Escornalbou de los casos raros de las Misiones y de las vidas de algunos venerables misioneros de dicho colegio, y de la serie de los guardianes, Ms. sin numerar, 1777.

Sermones misionales, Ms. sin numerar, Principios del siglo XVIII.

BUB

Plática de misión, Ms. 894, Principios del siglo XVIII.

Sermó de missió, Ms. 693, Finales del siglo XVII.

Sermón misional, Ms. 694. Finales del siglo XVII.

\section{FUENTES IMPRESAS}

Acevedo, A. Catecismo de los misterios de la Fe, con la exposición del Símbolo de los Santos Apóstoles, donde se enseña todo lo que un fiel christiano está obligado a creer, y su cura de almas a saber, para enseñar a sus ovejas, Barcelona, 1589. 
Carabantes, J. Pláticas o lecciones muy doctrinales sobre los Evangelios de las Dominicas de todo el año, para desempeño de los padres de almas, y de familias, y aprovechamiento de los que están a su cargo, Barcelona, 1685.

Confessional, Barcelona, 1535.

Marsal, A. Catecismo explicado y predicado, Barcelona, 1717.

Ordenanzas Generales de la Armada: parte primera sobre la gobernación militar, y marinera de la armada en general, y uso de sus fuerzas en la mar, Madrid, 1793.

Plens, J. Catechisme pastoral de pláticas doctrinals, y espirituals, per tots los diumenges del any, Barcelona, 1699.

Romeu, F. Cura pastoral de almas en diez sermones, Siglo XVIII.

Salses, P. Promptuari moral sagrat, y cathecisme pastoral de pláticas doctrinals y espirituals sobre tots los puntos de la doctrina christiana per predicar en la Quaresma, Diumenges, y demes festivitats, Rogativas per aygua, y altres necessitats Barcelona, 1754.

\section{BIBLIOGRAFÍA}

Amelang, J. S. Historias paralelas. Judeoconversos y moriscos en la España moderna, Madrid, 2012.

Armenteros Martínez, I. «Si tu non delinquiris. Conflictividad en torno a la esclavitud en la Barcelona tardomedieval», Anuario de Estudios Medievales 38/2 (2002) 967-1007.

Bakntin, M. La cultura popular en la Edad Media y el Renacimiento. El contexto cultural de François Rabelais, (tr.rusa), Barcelona, 1974.

Benveniste, E. «Blasphèmie et euphemie», Problèmes de linguistique générale, Vol. III, París, (1974) 251-256.

Berriot, F. Athéisme et athéistes en France au XVIe siècle, Paris, 1986.

Bethencourt, F. L'Inquisition à l'époque moderne: Espagne, Portugal, Italie, XVe-XIXe siècle, Paris, 1998.

Blázquez Miguel, J. La Inquisición en Albacete, Instituto de Estudios Albacetenses, Albacete, 1985.

Blázquez Miguel, J. La Inquisición en Cataluña. El tribunal del Santo Oficio de Barcelona, 1487-1820, Toledo, 1990.

Boeglin, M. «Disciplina religiosa y asentamientos de la doctrina: el delito de proposiciones ante la Inquisición de Sevilla», Historia, Instituciones, Documentos 30 (2003) 121144.

Boeglin, M. Inquisición y Contrarreforma. El tribunal del Santo Oficio de Sevilla, 1560-1700, Ayuntamiento de Sevilla, 2006.

Borras Galceran, J. «Geografia i incidències històriques de les missions populars d'Escornalbou», I Congrés d'Història de l'Església Catalana. Des dels origens fins ara, Vol. II, Solsona (1993) 93-114.

Cabantous, A. Histoire du blasphème en Occident, XVIe-XIXe siècle, Paris, 1998. 
Cabantous, A. Le ciel dans la mer. Christianisme et civilisation maritime, XVe-XIXe siècle, Paris, 1990.

Caro Baroja, J. Las formas complejas de la vida religiosa (Religión, sociedad y carácter en la España de los siglos XVI y XVII), Madrid, 2000.

Caro Baroja, J. Los judios en la España Moderna y Contemporánea, Madrid, 2000.

Caro Baroja, J. De la superstición al ateísmo (meditaciones antropológicas), Madrid. 1974.

Casanovas Miró, J. «Aspectos cotidianos de la relación entre judíos y cristianos: la imagen que del judío tiene el cristiano», Y. Moreno Kock, R. Izquierdo (eds.), Del pasado judío en los reinos medievales hispanos, Universidad de Castilla-La Mancha, Toledo (2005) 99-134.

Chablanc, A. «Averroes, Maimónides y la crisis en la comunidad judía medieval», Anales del Seminario de Historia de la Filosofía 22 (2005) 111-123.

Cilveti, A. El demonio en el teatro de Calderón, Valencia, 1977.

Cristóbal Martín, M. A. «La Inquisición de Logroño. Mentalidad popular en el agro riojano», II Coloquio de Historia de La Rioja, Vol. II, Instituto de Estudios Riojanos, Logroño (1986) 83-90.

Dedieu, J. P. «El modelo religioso: las disciplinas del lenguaje y de la acción», B. Bennassar (ed.), La Inquisición española: poder político y control social (tr. fr.), Barcelona (1981) 208-230.

Delgado Ruíz, M. «La antirreligiosidad popular en España», C. Álvarez Santaló, M. J. Buxó Rey, S. Rodriguez Becerra (eds.), La religiosidad popular. Antropología e historia, Vol. III, Barcelona (1989) 499-514.

Delumeau, J. La peur en Occident. Une cité assiegée (XIVe-XVIIIe siècles), Paris, 1978.

Febvre, L. Le problème de l'incroyance au XVI siècle. La religión de Rabelais, Paris, 1947.

Ferrer Valls, T. «Las dos caras del diablo en el teatro antiguo español», M. Chiabó, F. Doglio (eds.), Atti di XII Convegno di Studi sul Teatro Medioevale e Rinascimento, Centro de Studi sul Teatro Medioevale e Rinascimentales, Roma (1989) 303-324.

Flynn, M. «Blasphemy and the play of the anger in sixteenth Century Spain», Past and Present 149 (1995) 29-56.

García Arenal, M. Inquisición y moriscos: los procesos del tribunal de Cuenca, Madrid, 1978.

García Casar, M. F. «De la Sefarad judía a la España conversa», El legado sefardí. Memoria de Sefarad, Universidad de Castilla-La Mancha, Toledo (2002) 425-439.

García Pedraz, A. Actitudes acerca de la muerte en la Granada del siglo XVI: los moriscos que quisieron salvarse, Universidad de Granada, 2002.

Gelabertó Vilagran, M. «Inquisición y blasfemias en la Cataluña de los siglos XVI y XVII», Pedralbes. Revista d'història moderna 28 (2010) 651-676.

Gómez, M. P. «La ciutat de Lleida contra blasfems, heretges i bruixes», Miscel.lània. Homenatge a Josep Lladonosa, Lleida (1992) 380-392.

Granada Martínez, M. A. «El averroísmo en Europa», Averroes y los averroísmos (Actas del III Congreso de Filosofia Medieval), Zaragoza (1998) 163-182.

Hernando, J. «La Inquisición en Cataluña en la Baja Edad Media. Un proceso por crimen de herejía contra el ciudadano de Barcelona Pere Març», Clio\&Crimen 2 (2005) 127-174. 
Horeau-Dodinau, J. «Le blasphème au Moyen Âge. Une aproche juridique», Atalaya. Revue française d'Études Médiévales 5 (1994) 193-210.

Huizinga, J. Le déclin du Moyen Âge, (tr.fr.). Paris, 1948.

Kamen, H. Cambio cultural en la sociedad del Siglo de Oro. Cataluña y Castilla, siglos XVIXVII, (tra. esp.), Madrid, 1998.

Kristeller, P. O. «Le mythe de l'atheisme de la Renaissance et la tradition française de la libre pensée», Bibliothèque d'humanisme et Renaissance. Travaux et documents 37/1 (1975) 337-348.

Le Roy Ladurie, E. Montaillou, village occitain, Paris, 1975.

Lebègne, R. «Le diable dans l'ancien théâtre religieux», Communication au III Congrés de l' Association, Paris (1951) 93-106.

Llompart, G. «Blasfemias y juramentos cristológicos en la Baja Edad Media catalana», Hispania Sacra 27 (1973) 137-164.

Márquez Villanueva, F. «El caso del averroísmo popular», R. Beltrán, J. L. Canet (eds.), Cinco siglos de Celestina: aportaciones interpretativas, Universidad de Valencia (1987) 121-132.

Márquez Villanueva, F. «Nacer e morir como bestias: criptojudaísmo y criptoaverroísmo», F. Díaz Esteban (ed.), Los judaizantes en Europa y la literatura del Siglo de Oro, Madrid (1994) 273-293.

Millas Vallicrosa, J. M. Vendrell Gallestra, F. «La aljama de Barcelona», Miscel.lanea Barcinonensia 16 (1967) 9-17.

Minois, G. Histoire de l'athéisme. Les incroyants dans le monde occidental des origines à nos jours, Paris, 1988.

Mollat, M. Attitudes religieuses et morales des pécheurs, Paris, 1982.

Monter, W. La otra Inquisición (tr. ingl.), Barcelona, 1992.

Muchembled, R. L'invection de l'homme moderne. Cultures et sensibilités en France du XV au XVIII siècle, Paris, 1988.

Muchembled, R. Une histoire du diable, XIIe-XXe siècle, Paris, 2000.

Oliveira Ribas, R, Moriscos, crypto-Islamismo e Inquisiçao no Portugal Quinheista, Universidade de Lisboa, 2 Vols, 2004.

Omont, H. «Memorial de l'Inquisition d'Aragon à la fin du XIVe siècle», Bibliothèque de l'Ecole de Chartres 66 (1905) 261-268.

Palma de Mallorca, A. Prat de Llobregat (ensayo histórico), Prat de Llobregat, 1958.

Pelosse, V. «Imaginaire social et protection de l'animal. Des amis des bêtes de l'an X au legislateur de 1850», L'Homme 21/4 (1981) 5-53.

Pérez, J. Los judios en España, Madrid, 2003.

Quatrefages, R. «Les militaires et le pouvoir dans le monde ibérique», Mélanges de la Casa de Velázquez 14 (1978) 537-547.

Rábade Obradó, M. P. «Expresiones de la religiosidad cristiana en los procesos contra los judaizantes del tribunal del Ciudad Real /Toledo, 1483-1507», En la España medieval 13 (1990) 303-330. 
Renan, E. Pacheco, H. Averroes y el averroísmo (ensayo histórico), Madrid, 1992.

Rossi, G. «Calderón en la polémica setecentista sobre los Autos Sacramentales». Estudios sobre las letras en el siglo XVIII (Biblioteca Románica Hispánica, Gredos), Madrid (1967) 9-96.

Schmitt, J-Cl. «La croyance au Moyen Âge», Raison presente 113 (1993) 126-140.

Schwart, S. B. Cada uno en su ley: salvación y tolerancia religiosa en el Atlántico barroco, (tr.ingl.), Madrid, 2010.

Sommerville, J. «Religious faith, doubt and atheisme», Past and Present 128 (1990) 78-94.

Taylor, Ch. «The Rusdhie controversy», C. A. Breckerindge (ed.), Public culture. Bulletin of the center for transnacional cultural studies, University of Pennsylvania Press (1989) 79-127.

Thomas, K. Religion and the decline of magic, London, 1971.

Usunáriz, J. M. «Verbum Maledictionis. La blasfemia y el blasfemo de los siglos XVI y XVII», R. García Bourrellier, J. M. Usunáriz (eds.), Aportaciones a la historia social del lenguaje: España (siglos XIV-XVIII), Madrid (2006) 197-221.

Villanueva, J. «Remarques à propos de l'historiographie sur le libertinisme espagnol du XVIIe siècle», Cahiers du Centre de Recherches Historiques 35 (2005) 85-103.

Vinyoles, J. «Catalan blasphemies», Maledicta 7 (1983) 99-110.

Vinyoles, M. T. «La violencia marginal a les ciutats medievals (exemples a la Barcelona dels volts del 1400)», Revista d'història medieval 1 (1990) 155-177.

Wirth, J. «Naissance du concept de croyance, XII-XVI siècle», Bibliothèque d'humanisme et Renaissance. Travaux et documents (tr. fr.), 45/1 (1983) 298-315. 